\title{
Can a State's Water Rights Be Damned? Environmental Flows and Federal Dams in the Supreme Court
}

\author{
Reed D. Benson \\ University of New Mexico - School of Law
}

Follow this and additional works at: https://digitalrepository.unm.edu/law_facultyscholarship

Part of the Environmental Law Commons, and the Water Law Commons

\section{Recommended Citation}

Reed D. Benson, Can a State's Water Rights Be Damned? Environmental Flows and Federal Dams in the Supreme Court, 8 Michigan Journal of Environmental and Administrative Law 371 (2019).

Available at: https://digitalrepository.unm.edu/law_facultyscholarship/744

This Article is brought to you for free and open access by the UNM School of Law at UNM Digital Repository. It has been accepted for inclusion in Faculty Scholarship by an authorized administrator of UNM Digital Repository. For more information, please contact amywinter@unm.edu, Isloane@salud.unm.edu,sarahrk@unm.edu.

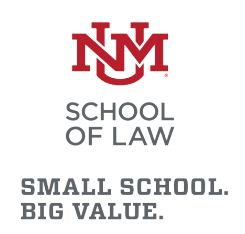




\title{
CAN A STATE'S WATER RIGHTS BE DAMMED? ENVIRONMENTAL FLOWS AND FEDERAL DAMS IN THE SUPREME COURT
}

\author{
Reed D. Benson*
}

\begin{abstract}
Interstate rivers are subject to the doctrine of equitable apportionment, whereby the Supreme Court seeks to ensure that all states that share such rivers get a fair portion of their benefits. The Court has rarely issued an equitable apportionment decree, however, and there is little law on whether the doctrine protects river flows for environmental purposes. The ongoing Florida v. Georgia litigation in the Supreme Court raises this issue, as Florida seeks to limit consumptive uses by upstream Georgia to preserve flows in the Apalachicola River, which provide both economic and environmental benefits. This Article summarizes both the equitable apportionment doctrine and the concept of environmental flows and then considers prior Supreme Court cases dealing with environmental issues on interstate rivers. It then examines Florida v. Georgia, including the Court's 2018 decision where it narrowly allowed the litigation to continue. A key issue in that decision was the role of the Army Corps of Engineers, which operates several federal dams in the river basin at issue in the case. This Article examines the views of the Court on the role of the Corps and its dam operations and contends that the Court focused too narrowly on the agency's existing plan while overlooking the broader legal and policy context. It concludes with some brief thoughts on the future of the Florida v. Georgia litigation and environmental flows.
\end{abstract}

* Dickason Chair and Professor, University of New Mexico School of Law. The author thanks James Grieco, UNM Law Class of 2019, for his excellent research assistance. He also thanks the Dickason endowment and the UNM School of Law for their financial support of the work that went into this Article. 


\section{TABLE OF CONTENTS}

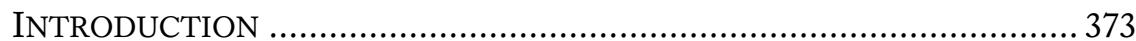

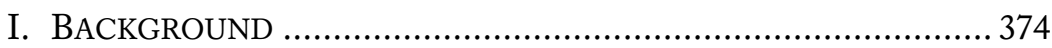

A. Equitable Apportionment in the Supreme Court ...................... 374

B. Corps of Engineers Water Projects.......................................... 377

C. Environmental Flows and the Law .......................................380

II. DoES THE EQUiTABLE APPORTIONMENT DOCTRINE PROTECT ENVIRONMENTAL FLOWS?.................................... 383

A. The Delaware River Case: Water Quality, Fish, and Recreation ....................................................................... 384

B. The Columbia Case: Interstate Fish Runs.................................386

C. The Second North Platte Case: Endangered Species Habitat.......389

III. FLORIDA V. GEORGIA: ENVIRONMENTAL FLOWS AND FEDERAL DAMS IN THE ACF BASIN..................................... 391

A. Prior Disputes and Corps Projects ........................................ 391

B. Florida's Equitable Apportionment Action .................................393

C. The Court's 2018 Decision ..................................................... 397

IV. CAN FEDERal Dams Block Equitable APPORTIONMENT?............................................................ 402

CONCLUSION ..................................................................... 407 


\section{INTRODUCTION}

"A river is more than an amenity, it is a treasure." Justice Oliver Wendell Holmes wrote those words almost 90 years ago in a Supreme Court decision involving an interstate water dispute over the Delaware River. ${ }^{2}$ That simple but eloquent statement suggests that the Court recognized the river for its natural values, as well as a source of water for economic activities. ${ }^{3}$

In the Delaware River case, the Court applied the doctrine of equitable apportionment to protect New Jersey's interest in the river's fisheries, water quality, and recreational uses, while giving New York a limited right to use it for municipal water supply. ${ }^{4}$ In subsequent cases involving other rivers, the Court has allowed states to assert an interest in water for environmental and recreational uses but has not clearly established that the equitable apportionment doctrine protects environmental flows.

Today, Florida is attempting to use the equitable apportionment doctrine to ensure adequate flows on the Apalachicola River in order to protect both the ecosystem that relies on the river and the oyster fishery in the river's estuary. While that fishery has commercial value, Florida is clearly seeking to defend environmental as well as economic interests in its Supreme Court litigation against Georgia, which is upstream. Having narrowly survived dismissal in a 5-4 decision at the end of the 2018 term, ${ }^{5}$ Florida's lawsuit lives on, giving the Court an opportunity to clarify how equitable apportionment applies to environmental flows in the modern era.

The key issue in the Court's recent decision was the role of the U.S. Army Corps of Engineers (the Corps), which operates several dams in the ApalachicolaChattahoochee-Flint (ACF) Basin. The dams form a system of federal water projects that the Corps operates to serve certain purposes - including hydropower, water supply, and recreation - as authorized by Congress. These dams play an important role in determining flow patterns in the Apalachicola, but because the federal government is not a party to the litigation, the Court has no power to order any change in the Corps' operations. A divided Court decided that the absence of the Corps did not necessarily preclude an effective judicial remedy for Florida.

1. New Jersey v. New York, 283 U.S. 336, 342 (1931).

2. Id. at 341 .

3. A mere five years later, however, the Court quoted the "treasure" line to emphasize the need to make maximum beneficial use of water in the arid West. Washington v. Oregon, 297 U.S. 517, 527 (1936). That case focused entirely on the use of the interstate Walla Walla River for irrigation and essentially allowed Oregon to continue drying up the river during the irrigation season. Id. at 522-24. In that case, at least, the Court viewed the river as a "treasure" only in the economic sense of the word.

4. New Jersey v. New York, 283 U.S. at 345-48.

5. Florida v. Georgia, 138 S. Ct. 2502 (2018). 
This Article begins by summarizing three disparate aspects of the ACF water dispute. First, this Article will examine the equitable apportionment doctrine as created and applied by the Court in interstate litigation. Next, it will describe water projects built and operated by the Corps in the ACF Basin. Finally, this Article will discuss the concept of environmental flows to support healthy rivers and riverdependent ecosystems. The following section considers Supreme Court decisions in interstate cases to determine whether environmental flows may be a relevant consideration under equitable apportionment. The Article then turns to the ongoing Florida v. Georgia case, briefly examining the dispute over water use in the ACF Basin, the Court's recent decision allowing the case to continue, and the statements in the opinion bearing on environmental flows. It then specifically addresses the Corps' role in the ACF Basin and argues that the Court focused too narrowly on the Corps' current ACF operating plan and overlooked the broader legal and policy context. The Article concludes with some brief thoughts on the future of the Florida v. Georgia litigation.

\section{BACKGROUND}

This section addresses three products of the twentieth century. Between 1900 and 1945, the Supreme Court announced the equitable apportionment doctrine, refined it in a series of interstate water cases, and applied it to allocate the water of three different river systems among the contending states. Beginning in the 1930s, Congress authorized the Corps to build dams for flood control and other purposes, and today the Corps operates hundreds of dams across the nation. The concept of environmental flows (or instream flows for environmental purposes) developed in the latter half of the twentieth century, as state and federal laws began recognizing the need for adequate flows to support fish populations and other features of riverdependent ecosystems. This section considers these developments, beginning with the law of equitable apportionment.

\section{A. Equitable Apportionment in the Supreme Court}

Lawsuits in which one state sues another are "original jurisdiction" cases that go directly to the Supreme Court, ${ }^{6}$ which appoints a special master to take evidence and prepare a series of reports on the disputed issues. The Court decides the matter after considering the reports and the parties' exceptions to them. ${ }^{7}$ When the first such case - a dispute between Kansas and Colorado over the waters of the Ar-

6. $\quad$ See U.S. CONST. art. III, $\S 2$.

7. See, e.g., Texas v. New Mexico, 482 U.S. 124 (1987). Litigation over the Pecos River involved a series of reports issued by a succession of special masters, with whom the Court sometimes disagreed on key points. Although that dispute was governed by the Pecos River Compact rather than the equitable apportionment doctrine, it provides a good illustration of the role of special masters in the Supreme Court's interstate water cases. 
kansas River $^{8}$ - reached the Court, there was no established law to apply. The Court developed and announced the equitable apportionment doctrine in Kansas $v$. Colorado. ${ }^{9}$ While the Court denied relief to downstream Kansas in that case, it allowed for a future suit if increased uses of the river in Colorado caused substantial injury to Kansas "to the extent of destroying the equitable apportionment of benefits between the two States resulting from the flow of the river." ${ }^{10}$

The Court refined and clarified the equitable apportionment doctrine over the next few decades in cases involving a variety of interstate waters, both eastern and western. The Court first apportioned a river in 1922, effectively protecting established irrigation uses of the Laramie River in Wyoming by limiting an upstream diversion to a different watershed in Colorado. ${ }^{11}$ Later cases would apportion the waters of the Delaware River, primarily between New York and New Jersey, ${ }^{12}$ and the North Platte, primarily between Wyoming and Nebraska. ${ }^{13}$ Although there would be later cases under the equitable apportionment doctrine, ${ }^{14}$ the North Platte decision of 1945 was the last time the Court issued a decree apportioning the waters of an interstate river.

Nebraska v. Wyoming is best known for its statement of the Court's approach in deciding an interstate water case under equitable apportionment:

Apportionment calls for the exercise of an informed judgment on a consideration of many factors .... [ [P]hysical and climatic conditions, the consumptive use of water in the several sections of the river, the character and rate of return flows, the extent of established uses, the availability of storage water, the practical effect of wasteful uses on downstream areas, the damage to upstream areas as compared to the benefits to downstream areas if a limitation is imposed on the former-these are all relevant factors. They are merely an illustrative not an exhaustive catalogue. They indicate the nature of the problem of apportionment and the delicate adjustment of interests which must be made. ${ }^{15}$

8. Kansas v. Colorado, 206 U.S. 46, 47-55 (1907).

9. Id. at 97-98 (stating that, where the actions of one State "through the agency of natural laws" had affected another State, the Court would seek to "recognize the equal rights of both and at the same time establish justice between them").

10. Id. at 118 .

11. Wyoming v. Colorado, 259 U.S. 419, 485-96 (1922).

12. New Jersey v. New York, 283 U.S. 336, 345-48 (1931). Pennsylvania was also a party to the case.

13. Nebraska v. Wyoming, 325 U.S. 589, 637-54, 667-69 (1945). Colorado was also a party to the case.

14. See, e.g., Colorado v. New Mexico (Colorado v. New Mexico I), 459 U.S. 176 (1982) and Colorado v. New Mexico (Colorado v. New Mexico II), 467 U.S. 310 (1984).

15. Nebraska v. Wyoming, 325 U.S. at 618. Because that case involved two states that allocate and manage water under the prior appropriation doctrine, whereby the longest-established uses get pri- 
Thus, equitable apportionment can be viewed as a totality-of-the-circumstances test, and the Court has emphasized that in these cases it is more concerned with fairness than formulas. ${ }^{16}$

In deciding what is fair, however, the Court has repeatedly chosen to protect established water uses and the local economies that rely on them. This is a recurring theme in cases involving western rivers where the contending states employ the prior appropriation doctrine, under which the longest-established uses take priority over later ones during times of water shortage. ${ }^{17}$ But where state laws may give absolute priority to the earliest uses, the Court has said only that "priority of appropriation is the guiding principle," ${ }^{18}$ which may prove less important than protecting established but junior users. "So far as possible those established uses should be protected though strict application of the priority rule might jeopardize them." ${ }^{19}$

From its early interstate water cases to the present, the Court has stressed a related point: a state seeking relief under equitable apportionment carries a heavy burden of showing that the actions of another state are causing or will cause substantial harm to the plaintiff state's interests. Kansas v. Colorado established both the principle of equitable apportionment and the precedent that the Court may deny relief despite a showing of harm. ${ }^{20}$ The Court has repeatedly stated that before it will order a remedy in these interstate cases, "the threatened invasion of rights must be of serious magnitude and it must be established by clear and convincing evidence." ${ }^{21}$ More than once the Court has denied relief when it certainly could have concluded that a state was using more than its fair share of an interstate river. $^{22}$

In addition to this judicial bar, there is another key reason why the Supreme Court has apportioned so few rivers: it has repeatedly urged states to resolve water disputes through negotiated compacts rather than litigation. As the Court noted

ority during times when water supplies are short, the Court also noted that "[p]riority of appropriation is the guiding principle." Id. The Court emphasized, however, that it might favor protecting established uses over strictly enforcing temporal priorities. "So far as possible those established uses should be protected though strict application of the priority rule might jeopardize them." Id.

16. Florida v. Georgia, 138 S. Ct. 2502, 2513 (2018) (quoting New Jersey v. New York, 283 U.S. at 342-43).

17. See Wyoming v. Colorado, 259 U.S. 419 (1922); Washington v. Oregon, 297 U.S. 517 (1936); Nebraska v. Wyoming, 325 U.S. 589 (1945); Colorado v. New Mexico II, 467 U.S. 310 (1984).

18. Nebraska v. Wyoming, 325 U.S. at 618.

19. Id.

20. Kansas v. Colorado, 206 U.S 46, 117-18 (1907).

21. Washington v. Oregon, 297 U.S. at 522 (quoting New York v. New Jersey, 256 U.S. 296, 309 (1921)); see also Florida v. Georgia, 138 S. Ct. at 2514-15 (citing and quoting various cases regarding the nature of the required harm and the standard of proof).

22. See, e.g., Washington v. Oregon, 297 U.S. at 522-23 (Oregon irrigators nearly drying up the Walla Walla River at the state line); Colorado v. New Mexico II, 467 U.S. at 323-24 (New Mexico uses a majority of the water of the Vermejo River, even though $75 \%$ of that water originates in Colorado.). 
near the outset of its latest equitable apportionment decision, ${ }^{23}$ despite its authority to adjudicate interstate water disputes, "we have long noted our 'preference' that States 'settle their controversies by 'mutual accommodation and agreement.", 24 Thus, compacts - negotiated by the interested states, ratified by those states, and approved by Congress - are by far the more common means of dividing the waters of interstate rivers, especially in the West. ${ }^{25}$ Compacts have certainly not kept states from litigating their water disputes in the Supreme Court, ${ }^{26}$ but when they do, the rule of decision becomes the terms of the relevant compact rather than the doctrine of equitable apportionment. ${ }^{27}$

\section{B. Corps of Engineers Water Projects}

The Corps has been a prolific dam-builder since the Flood Control Act of 1936 made flood control a federal activity. ${ }^{28}$ This Act made the Corps responsible for "[f]ederal investigations and improvements of rivers and other waterways for flood control and allied purposes...." ${ }^{29}$ Recognizing that flood-control dams could serve additional uses, Congress authorized the Corps to build multi-purpose projects for "an expanding array of public purposes that included flood control, hydropower, flat water recreation, and even irrigation and municipal water supply." 30 The Corps today owns and operates over 600 dams that can generate nearly a quarter of the nation's hydropower and store nearly 330 million acre-feet, ${ }^{31}$ that helped prevent nearly half a trillion dollars in flood damages over the course of a recent

23. Florida v. Georgia, No. 142, Orig., (S.Ct. filed June 27, 2018) [hereinafter Florida v. Georgia slip op.].

24. Id., slip op. 3 (quoting Arizona v. California, 373 U.S. 546, 564 (1963), in turn quoting Colorado v. Kansas, 320 U.S. 383, 392 (1943)).

25. Whereas only three rivers have been apportioned directly by the Supreme Court, there are over two dozen interstate water compacts, mostly apportioning western rivers. See Jerome C. Muys et al., Utton Transboundary Resources Center Model Interstate Water Compact, 47 NAT. RESOURCES J. 17, 21 (2007).

26. See, e.g., Texas v. New Mexico, 462 U.S. 554, 556 (1983) (Pecos River Compact); Kansas v. Colorado, 533 U.S. 1, 4-5 (2001) (Arkansas River Compact).

27. See Florida v. Georgia, 138 S. Ct. 2502, 2513 (2018) (noting that equitable apportionment principles apply in the absence of a compact).

28. Flood Control Act of 1936 Pub. L. No. 74-738, § 1, 49 Stat. 1570, 1570 (codified at 33 U.S.C. $\S 701 \mathrm{a}$ (2018)) (stating "the sense of Congress that flood control on navigable rivers or their tributaries is a proper activity of the Federal Government in cooperation with States" and local governments).

29. Id. $\S 2$ (codified at 33 U.S.C. $\S 701 \mathrm{~b}(2018)$ ). Congress provided, however, that the Corps' flood control work "shall not interfere with investigations and river improvements incident to reclamation projects" undertaken by the Bureau. Id.

30. Robert Haskell Abrams, Water Federalism and the Army Corps of Engineers' Role in Eastern States Water Allocation, 31 U. ARK. LiTTLE ROCK L. REV. 395, 396 (2009).

31. Mission Overview, U.S. ARMY CORPS OF ENGINEERS, http://www.usace.army.mil/ Missions.aspx (last visited June 10, 2015). 
decade, ${ }^{32}$ and that host 370 million recreational visitor days per year. ${ }^{33}$ While most Corps reservoirs are not involved with water supply, more than 100 of them make water available for municipal and industrial uses. ${ }^{34}$

The authorizing statute(s) for a project specify the purpose(s) for which that project was designed and constructed. ${ }^{35}$ Congress may authorize a project for multiple purposes, such as flood control, hydropower, and recreation, but give one purpose a higher or lower priority than others. ${ }^{36}$ These project purposes remain important today because the purposes generally dictate the operating priorities of a project. A statute authorizing a project for flood control and hydropower effectively requires the Corps to operate the dam to serve those purposes, while leaving the agency discretion to decide the specific operating practices - that is, the exact timing and quantity of reservoir storage and releases. ${ }^{37}$

The Corps' choices about reservoir operations make a difference, because operating a reservoir inevitably involves trade-offs between competing values. ${ }^{38}$ For example, reducing dam releases in a time of low river flows will raise reservoir levels and help protect against extended drought, but will stress downstream ecosystems during the time that releases are curtailed. Boosting hydropower production during times of peak demand will raise revenue because the price of electricity is higher in those times, but dramatic fluctuations in river levels cause problems for downstream ecosystems and recreation. In determining its operating practices for a project, the Corps must serve authorized purposes while considering the other values affected.

32. "USACE dams contributed to $\$ 485$ billion in damages prevented from 2004 to 2013 , with $\$ 13.4$ billion in damages prevented in 2013. USACE flood damage reduction projects avoid $\$ 8.00$ in damages for every $\$ 1.00$ invested.” Dam Safety Facts and Figures, U.S. ARMY CORPS OF ENGINEERS, http://www.usace.army.mil/Media/FactSheets/FactSheetArticleView/tabid/219/Article/590578/damsafety-facts-and-figures.aspx (last visited June 10, 2015).

33. News Release, U.S. Army Corps of Eng'rs, U.S. Army Corps of Engineers to Conduct Visitor Surveys at Recreation Areas Beginning this Spring (Feb. 19, 2013), http://www.usace.army.mil/ Media/News-Release-Article-View/Article/475446/us-army-corps-of-engineers-to-conduct-visitorsurveys-at-recreation-areas-begin/.

34. A Congressional Research Service report states that "133 Corps multi-purpose reservoirs in 26 states have 11.1 million acre-feet of storage space" for municipal and industrial water supply. Cynthia Brougher \& Nicole T. CARTer, Cong. Research Serv., R42805, REallocation of WAter Storage at Federal Water Projects For Municipal and Industrial Water SUPPLY 3 (2012).

35. Reed D. Benson, Reviewing Reservoir Operations: Can Federal Water Projects Adapt to Change?, 42 Colum. J. ENVTL. L. 353, 368 (2017).

36. Id. at $368-70$.

37. See id. at 369 .

38. Id. at 364-67 (discussing examples of such trade-offs, drawn from litigation over Corps and Bureau of Reclamation project operations). 
The Corps' operating regime for a project is detailed in a "water control plan" that is geared to the project's authorizing legislation and other relevant law. ${ }^{39} \mathrm{Wa}$ ter control plans must "include coordinated regulation schedules" for operating a project or set or projects, and provide for detailed operating instructions to ensure that the project meets its authorized purposes. ${ }^{40}$ The Corps incorporates the plan for a project into a water control manual for that project. ${ }^{41}$ In a river basin with multiple projects that have related purposes, the Corps will produce a "master manual" for coordinated operation of the system. ${ }^{42} \mathrm{~A}$ water control manual may bind the Corps to operate its project(s) in accordance with the terms of the manual, subject to judicial review. ${ }^{43}$

The Corps must comply with key environmental laws in developing or revising its water control manuals. The National Environmental Policy Act (NEPA) ${ }^{44}$ requires a federal agency to assess potential environmental impacts and to consider alternatives before taking any action that could significantly affect the quality of the human environment. ${ }^{45}$ Thus, the Corps produces an Environmental Impact Statement (EIS) in the process of updating a project manual. ${ }^{46}$ While NEPA imposes only procedural duties, the Endangered Species Act (ESA) ${ }^{47}$ imposes key substantive obligations on the Corps. Most significantly, ESA Section 7 commands that every federal agency "shall ... insure that any action authorized, funded, or carried out by such agency.... is not likely to jeopardize the continued existence"

39. DEP'T OF THE ARMY, U.S. ARMY CORPS OF ENG'RS, No. 1110-2-240, ENGINEERING AND Design - Water Control Management, Engineer Regulation (2016) [hereinafter Water Control Management Rule]. The 2016 rule superseded an earlier rule of the same number, adopted in 1982. Id., para. 1-1(b).

40. Id., para. 3-2(b)

41. Id., para. 3-1(f) (A manual must contain additional elements beyond the water control plan, including special operating or management rules for "emergency situations, including droughts. . . .").

42. Id., para. 3-1(a).

43. See South Dakota v. Ubbelohde, 330 F.3d 1014 (8th Cir. 2003). The requirement for water control plans stems from Section 7 of the Flood Control Act of 1944, directing the Corps "to prescribe regulations for the use of storage allocated for flood control or navigation at all reservoirs constructed wholly or in part with Federal funds provided on the basis of such purposes, and the operation of any such project shall be in accordance with such purposes." Flood Control Act of 1944, 33 U.S.C. $\S 709$ (2012).

44. See generally 42 U.S.C. $\S \S 4321-4370 f(2017)$.

45. 42 U.S.C. $\S 4332(2)(C)(2012)$. NEPA $\S 102(2)$ applies to all agencies of the federal government and states several requirements in addition to the "detailed statement" mandate of subsection (C), one of which is to "study, develop, and describe appropriate alternatives to recommended courses of action in any proposal which involves unresolved conflicts concerning alternative uses of available resources." 42 U.S.C. $\S 4332(2)(E)$ (2012).

46. See In re Operation of Mo. River Sys. Litig., 421 F.3d 618, 627 (8th Cir. 2005) (noting that the Corps produced an Environmental Impact Statement in the process of updating its "master manual" for operating its projects in the Missouri River System).

47. 16 U.S.C. $\S \S 1531-1544$ (2012). 
of any threatened species, or adversely modify its designated critical habitat. ${ }^{48}$ More than any other environmental law, the ESA has forced the Corps and other water managers to evaluate and mitigate the environmental impacts of their operations, such as by adjusting reservoir releases to benefit downstream ecosystems. ${ }^{49}$

\section{Environmental Flows and the Law}

The concept of environmental flows is simple: a river must have enough flowing water to sustain its natural functions and the living things that depend on it. Environmental protection, especially protection of important fish populations, is a major reason why specific flow levels have been required or recommended on many rivers. ${ }^{50}$ Such prescribed flow levels are often referred to as "instream flows" to distinguish them from consumptive uses such as irrigation or municipal water supply, which require that water be withdrawn from the river and conveyed to an off-stream location. ${ }^{51}$

In practice, however, protection of environmental flows is typically not simple at all. The primary reason for this is that water suppliers, users, and decisionmakers are often wary of environmental flow requirements, believing they may limit access to water for other uses. ${ }^{52}$ In many places (especially in the West) the conflict between consumptive uses and environmental flows is very real ${ }^{53}$ as many rivers have been depleted by water withdrawals to irrigate crops, operate power plants, and supply municipal and industrial users. ${ }^{54}$ Thus, existing water uses commonly remove enough water from a river system to leave remaining flows inadequate for environmental needs. ${ }^{55}$

48. 16 U.S.C. $\S 1536(a)(2)$ (2012).

49. Benson, supra note 35, at 378-83 (noting effects of the ESA on project operations and general ineffectiveness of other environmental laws in this context).

50. See Cynthia F. Covell et al., Update to a Survey of State Instream Flow Programs in the Western United States, 20 U. DENV. WATER L. REV. 355, 368 (2017) (noting that "instream flow water rights to protect fisheries, aquatic habitat, and similar environmental values have become accepted as beneficial uses of water in most western states," and likewise instream flow rights for recreation, water quality, and other purposes are recognized "in some states").

51. See David M. Gillilan \& Thomas C. Brown, Instream Flow Protection 1-4 (1997).

52. See id. at 133-35.

53. See id. at 39-40 (naming several major western rivers as "dry or virtually dry during substantial portions of the year").

54. This phenomenon is not limited to the West, as irrigation and power plant withdrawals, especially, have approached or exceeded the available water supplies in certain watersheds throughout the nation. See Kristen Averyt et al., Sectoral Contributions to Surface Water Stress in the Coterminous United States, ENVTL. RES. LeTTERS, July-Sept. 2013, at 3-4.

55. Thomas C. AnNear et al., Instream Flow Council, InStream Flows for RIVERINE RESOURCE STEWARDSHIP 2-3 (2002). 
The operation of dams and reservoirs can also alter river flows to the detriment of the downstream environment. The United States has over 75,000 dams, ${ }^{56}$ which store and release water to serve a variety of purposes such as hydropower generation, water supply, flood control, and reservoir recreation. Along with these important benefits, however, dams have adversely affected downstream ecosystems by altering natural flow patterns and trapping sediment, among other things. ${ }^{57}$ In the words of a leading researcher on dams where river systems have been most intensively impounded, "environmental costs of dams in the form of disrupted downstream hydrologic and biotic systems are likely to be greater in those regions than elsewhere." 58

In addition to the challenges posed by dams and consumptive uses, establishing and protecting environmental flows can be complicated for at least two further reasons. First, there may be multiple environmental resources or values that depend on flow levels. These resources or values may include fish of various species, other wildlife (from birds to aquatic invertebrates), riparian trees or other vegetation, and water quality to name just a few. ${ }^{59}$ To the extent that their flow requirements differ in quantity or timing, these resources may pose trade-offs in determining and managing environmental flows. ${ }^{60}$ Second, even for a single environmental factor - such as an endangered fish species - there may be considerable uncertainty and disagreement regarding its specific flow requirements. Thus, there may be no clear answer regarding acceptable environmental flows for that species in terms of how much water it needs (or how little it can tolerate). ${ }^{61}$

56. William L. Graf, Dam Nation: A Geographic Census of American Dams and Their Large-Scale Hydrologic Impacts, 35 WATER RESOURCES RES. 1305, 1305 (1999) (describing Corps of Engineers and Federal Emergency Management Agency census of U.S. dams exceeding 6 feet tall with 50 acre-feet of storage capacity, or 25 feet tall with 15 acre-feet of storage capacity).

57. Id. at $1305,1308$.

58. Id. at 1308 (noting that the heavily dammed northern Great Plains, Rocky Mountains, and Southwest regions "export water or water-related services [to other regions] while retaining the environmental costs”).

59. ANNEAR ET AL., supra note 55, at 21-49 (analyzing various factors to be considered in developing flow protection regimes).

60. For example, in updating its long-term operating regime for Glen Canyon Dam on the Colorado River, the Interior Department had to balance the needs of a popular trout fishery just below the dam; the endangered humpback chub further downstream; and the broader Grand Canyon ecosystem, including the riverside beaches relied upon by rafters. See, e.g., U.S. DEP'T OF THE INTERIOR, RECORD of Decision For the GLEN CANYON DAM LONG-TERM EXPERIMENTAL AND MANAGEMENT Plan FinAl ENVIRONMENTAL IMPACT STATEMENT at 3-5 (2016).

61. Such disagreements have been the crux of much litigation over the impact of federal water project operations on endangered species. See, e.g., Pac. Coast Fed'n of Fishermen's Ass'ns v. Bureau of Reclamation, 426 F.3d 1082, 1087-95 (9th Cir. 2005) (rejecting federal agency conclusion that salmon in the Klamath River would not be jeopardized by eight years of flow levels lower than recommended by scientific studies). 
Despite these and other challenges, environmental flows have gained increasing acceptance and recognition under state laws. This is true even in the West, ${ }^{62}$ where existing consumptive water demands often exceed the naturally available supplies, ${ }^{63}$ and where environmental flow protections potentially could restrict development of new water supplies for growing populations. ${ }^{64}$ Most of the eastern states have also established some legal mechanism for protecting environmental flows, primarily for fisheries and water quality purposes. ${ }^{65}$ While state laws differ widely in several respects, ${ }^{66}$ there are a few general approaches by which these laws protect flows from impairment. These include setting aside a certain quantity of water that will not be available for new uses, restricting approval of new uses on a case-by-case basis, and establishing new water rights for to preserve a certain level of environmental flow. ${ }^{67}$

Federal law, by contrast, has no general framework for establishing and protecting environmental flows. Environmental flows may be protected under the reserved rights (or Winters) doctrine, ${ }^{68}$ where the federal government designated lands for an environmental purpose, and water is needed to fulfill that purpose. ${ }^{69}$ The Court denied environmental flow claims on national forest land, however, essentially stating that such federal claims should be construed narrowly. ${ }^{70}$ Another relevant law is the Federal Power Act, which requires licensing of non-federal hy-

62. As stated in a recent article surveying relevant developments in the West since 1998:

In the past twenty years, states have gained more experience with instream flows. Some programs have matured considerably as instream water rights have taken their place in states' priority systems . . . . Instream flow rights for a variety of uses are now an accepted type of water right in most western states ... .

Covell et al., supra note 50, at 356 .

63. Averyt et al., supra note 54, at 3-5.

64. Covell et al., supra note 50, at 355 .

65. Allan LOCKE ET AL., INTEgRATED APPROACHES TO RIVERINE RESOURCE STEWARDSHIP 299 (2008) (identifying 24 states east of (or bordering) the Mississippi River as having some type of instream flow law; "[m]ost protect only minimum flows to provide for delineated purposes, typically fisheries and water quality").

66. Id. at 287-302 (describing key elements of instream flow laws in various states, primarily in the western U.S.).

67. GILliLAN \& BROWN, supra note 51, at 137-45 (discussing use of such approaches in the western U.S. states).

68. The doctrine originated with Winters v. United States, 207 U.S. 564 (1908), in which the Supreme Court held that an Indian reservation has a right under federal law to enough water to fulfill the reservation's purposes.

69. See Cappaert v. United States, 426 U.S. 128, 140 (1976) (recognizing reserved water right for Devil's Hole National Monument, established to protect an underground pool in Nevada and the fish species endemic to that pool).

70. United States v. New Mexico, 438 U.S. 696, $702-03$ (1978) (reserved water rights should be recognized only for "primary purposes" for which lands were designated, and only for the amount minimally needed for such purposes). 
dropower projects by the Federal Energy Regulatory Commission (FERC). ${ }^{71} \mathrm{Up}$ on expiration of a license, "FERC relicensing" can require re-operation of the project to improve environmental flows, to the point of making the project uneconomical to operate. ${ }^{72}$ Ironically, while the Federal Power Act requires periodic review of operating conditions for non-federal hydropower projects, there is no similar requirement for federal dams and reservoirs operated by the Corps of Engineers or Bureau of Reclamation. ${ }^{73}$ The most effective environmental law in this context has been the ESA, ${ }^{74}$ especially as more fish and other aquatic species have been listed as threatened or endangered. ${ }^{75}$

Even though many states now provide for protection of environmental flows within their own borders, environmental flow requirements are generally absent from interstate water allocation compacts, at least in the West. In other words, these compacts - negotiated by the affected states and approved by Congress - essentially ignore environmental concerns in favor of allocating water for consumptive uses. ${ }^{76}$ Interstate river basins without a compact, however, are governed by the equitable apportionment doctrine, ${ }^{77}$ and the next section examines whether the existing doctrine recognizes environmental flows.

\section{DOES THE EQUiTABLE APPORTIONMENT DOCTRINE PROTECT ENVIRONMENTAL FLOWS?}

The Supreme Court has applied the equitable apportionment doctrine to interstate disputes involving several different river systems, both East and West. Although there is no clear precedent for a right to environmental flows on interstate rivers, the Court's equitable apportionment jurisprudence strongly suggests that the doctrine may be used to mitigate environmental harm caused by water development and use.

71. 16 U.S.C. $\S 817(1)(2012)$.

72. City of Tacoma v. Fed. Energy Regulatory Comm'n, 460 F.3d 53, $71-75$ (D.C. Cir. 2006) (upholding increased flows to be supplied by relicensed project, based on statutory requirements to balance hydropower and environmental interests).

73. Benson, supra note 35 , at $408-11$.

74. See In re Operation of Mo. River Sys. Litig., 421 F.3d 618, 625-27 (8th Cir. 2005); supra notes 47-48.

75. Benson, supra note 35 , at 378 .

76. See Reed D. Benson, Environmental Issues in the Allocation and Management of Western Interstate Rivers, 24 IND. INT'L \& COMP. L. REV. 183, 191-95 (2014) (addressing the absence of environmental provisions in western interstate water compacts). Even in basins governed by such compacts, however, the ESA has prompted efforts to improve environmental flows for the benefit of listed species. Id. at 195-202.

77. See Florida v. Georgia, 138 S. Ct. 2502, 2513 (2018). 


\section{A. The Delaware River Case: Water Quality, Fish, and Recreation}

One of the earliest equitable apportionment cases involved a dispute between three eastern states over the waters of the Delaware River system. New Jersey sued upstream New York in the Supreme Court, seeking to block a proposed diversion from tributaries of the Delaware to the Hudson River basin to supply municipal water to New York City. ${ }^{78}$ New York sought to divert 600 million gallons per day (mgd) for this purpose, but Pennsylvania - which had its own designs on using the river to supply water to greater Philadelphia - intervened and argued that New York's diversion should be limited to $440 \mathrm{mgd} .{ }^{79} \mathrm{New}$ Jersey took the position that New York had adequate supplies within the Hudson watershed and should be prohibited from diverting any water out of the Delaware River basin. ${ }^{80}$

New Jersey contended that depleted flows caused by New York's diversion would harm New Jersey in various ways, some of which were purely economic: impairment of navigation, reduction in water power for riparian lands, and degradation of water quality to the detriment of industrial users. ${ }^{81}$ Crucially, however, New Jersey argued further that the diversion would do substantial harm to the Delaware's "use and value for recreation; to the oyster industry; to fish; to agriculture; and from the standpoint of sanitation and water supply." ${ }^{82}$ These alleged injuries certainly raised economic concerns, but also affected environmental, recreational, and public health interests.

The special master's report ${ }^{83}$ essentially found that New Jersey failed to prove that the proposed diversion would cause the alleged economic injuries. It specifically found no harm to navigability, ${ }^{84}$ and no likely impairment to potential hydropower generation. ${ }^{85}$ The Court also summarized the report as finding that the proposed 600 mgd diversion would not "materially affect the River or its sanitary condition, or as a source of municipal water supply, or for industrial uses, or for agriculture, or for the fisheries for shad." ${ }^{86}$ Thus, the master's report said that even

78. New Jersey v. New York, 283 U.S. 336, 341-42 (1931).

79. Id. at 345 (referring to a "Pennsylvania plan" that included a $440 \mathrm{mgd}$ limit on New York's proposed diversion).

80. This argument relied on the common law of riparian rights, which New Jersey argued should apply to this dispute between three states that recognize riparian rights. Id. at 338-39.

81. Id.

82. Id. at 339. This quote comes from the statement of New Jersey's position, which precedes Justice Holmes' opinion. The opinion itself restates New Jersey's list of alleged harms, clarifying that the oyster industry may be harmed by increasing salinity in the lower river and the Delaware Bay estuary; that the key fish species of concern was shad; and that agriculture may be harmed by lower river levels that "injure the cultivation of adjoining lands." Id. at 343-44.

83. The court praised the master's report as "most competent and excellent ...." Id. at 343.

84. The testimony of a high-level Corps of Engineers general was apparently influential on this point. Id. at 344 .

85. Id. at 345 .

86. Id. 
at the maximum proposed level, New York's diversion would cause none of the kinds of injuries that would seem to carry the greatest economic weight.

But all was not lost for New Jersey, as the report also found that at the proposed level of $600 \mathrm{mgd}$, "the effect upon the use for recreation and upon its reputation in that regard will be somewhat more serious, as will be the effect of increased salinity of the river on the oyster fisheries. The total is found to be greater than New Jersey ought to bear... ." ${ }^{87}$ The Court did not discuss the potential economic significance of either recreational use of the Delaware or the riverdependent oyster fisheries, but harm to those two interests prompted the special master's report to recommend - and the Court to adopt - three important conditions on New York's proposed diversion for municipal water supply.

The Court found that New Jersey's harm could be "removed" by, first, limiting New York's diversion to $440 \mathrm{mgd}$ - a reduction of over $25 \%$ from the proposed level. ${ }^{88}$ Second, the Court ordered New York to build and operate a wastewater treatment plant at Port Jervis to keep that town's sewage and industrial waste from polluting the Delaware. ${ }^{89}$ The Court imposed specific performance requirements on this plant ${ }^{90}$ without explaining why water quality improvement was necessary to reduce harm to oyster fisheries or recreational uses. Third, the Court required that water be released from one of New York City's reservoirs as needed to maintain specified minimum flows in the Delaware at Port Jervis and at Trenton, New Jersey. ${ }^{91}$ Thus, the Court protected flows for oysters and recreation not only by limiting diversions, but also by ordering release of stored water to ensure specified levels of the Delaware River.

This result is all the more remarkable because of the outcome of a factually similar case that the Court decided about 70 days before New Jersey v. New York. In that earlier case, Connecticut sued upstream Massachusetts to block a proposed diversion of water for Boston's municipal supply from tributaries of the Connecticut River. ${ }^{92}$ Connecticut argued that this diversion would harm many of the same

87. $I d$.

88. Id. at 345-46. The Court did not explain why it (or the special master) chose this specific level of diversion.

89. Id. at 346 .

90. The Court directed that the Port Jervis plant must treat the town's sewage and industrial wastewater to the degree that "organic impurities" would be reduced by 85 percent; "that the B. coli originally present in the sewage" be reduced by $90 \%$; and that the resulting effluent be "practically free from suspended matter and non-putrescent." The decree ordered that the plant be maintained so long as New York diverted water from the Delaware River system. Id. at 346.

91. The Court stated these minimum flows as being 1,535 cubic feet per second (cfs) at Port Jervis, and 3,400 cfs at Trenton. The Court generally required reservoir releases as needed to maintain these minimum levels but allowed for lower releases under specified circumstances. Id. at 346-47. The Court did not explain the source of these minimum levels.

92. Connecticut v. Massachusetts, 282 U.S. 660, 662 (1931). The Court decided this case on Feb. 24, and New Jersey v. New York on May 4, 1931. 
interests that New Jersey invoked in the Delaware River case, including navigation, hydropower, agriculture, a shad fishery, and sanitation. ${ }^{93}$ Accepting the special master's report, the Court denied the requested injunction declaring that "[d]rinking and other domestic purposes are the highest uses of water." ${ }^{94}$ Essentially, Massachusetts convinced the special master that its proposed diversion was the best option for meeting Boston's real need for additional water, ${ }^{95}$ while Connecticut failed to show serious injury from the proposed diversion. ${ }^{96}$ Importantly, however, Massachusetts was already required to ensure minimum flows in the Connecticut River under a decision of the War Department to ensure adequate levels for navigation. ${ }^{97}$ The Court denied relief not because water quality and fisheries concerns were unimportant in an equitable apportionment case but because Connecticut could not show significant harm to those interests. ${ }^{98}$

\section{B. The Columbia Case: Interstate Fish Runs}

Nearly half a century after deciding those eastern cases, the Court took up Idaho's lawsuit against Oregon and Washington over the Columbia-Snake River system. ${ }^{99}$ This was a different kind of equitable apportionment proceeding, however, because upstream Idaho sought to protect its interests not in water, but in salmon runs. ${ }^{100}$

93. Id. at 664. Missing from this list, however, are the two harms - oyster fishing and recreation - that the Court found in the Delaware River case.

94. Id. at 673. The Court cited no authority for this statement.

95. The special master's report found that greater Boston was "faced with a serious water shortage in the near future" that would require "a large quantity of additional water," and that there was "no serious dispute” about Boston's need for more water. Id. at 664-65. Connecticut argued that Boston could get the water from two other sources within Massachusetts, but the special master found that those sources were inferior, largely because the available water was polluted by upstream cities and industries. Id. at 667-69.

96. Id. at 672 (finding nothing in the master's report "to justify an inference that any real or substantial injury or damage will presently result to Connecticut from the diversions of Massachusetts ....")

97. Similar to the Supreme Court decision on the Delaware, the War Department approval for Boston's diversion required releases from storage in order to ensure specified minimum flows in the Connecticut. Id. at 665. Massachusetts told the Court that it would comply with these conditions. Id. at 666.

98. When the Court stated flatly, "No discussion is required as to the effect of the proposed diversion upon the navigability of the river, agriculture, fish life or pollution in Connecticut," id. at 672, it was because the special master's report had found no harm to those interests. Id. at 665-67. Harm to Connecticut's interest in hydropower development was a closer call on the facts, $i d$. at 673 , but nothing in the opinion suggests that fish and water quality are lesser interests than navigation, agriculture, or hydropower for purposes of equitable apportionment.

99. Idaho ex rel. Evans v. Oregon, 429 U.S. 163 (1976) (granting Idaho leave to file complaint); Idaho ex rel. Evans v. Oregon 431 U.S. 952 (1977) (referring the matter to a special master).

100. Idaho ex rel. Evans v. Oregon (Idaho I), 444 U.S. 380, 385 (1980). 
As explained by the Court in its final opinion in this litigation (Idaho II), ${ }^{101}$ these salmon runs are "one of the valuable natural resources of the ColumbiaSnake River system in the Pacific Northwest." 102 Juvenile salmon hatch from eggs in the freshwater rivers of Idaho, Oregon, and Washington. As juvenile "smolts" they migrate downriver to the ocean where they spend most of their lives. As adults they return to their home rivers to spawn, and the fish of a given species that return in a particular season are referred to as a "run." ${ }^{103}$ Idaho's lawsuit involved two runs of chinook salmon and one of steelhead trout, ${ }^{104}$ and as the Court noted, "runs of all the relevant species since 1973 have been significantly lower." 105

On the key threshold issue, the Court ruled in Idaho I that the equitable apportionment doctrine applied to fish and gave Idaho a right to its fair share of the interstate runs. The Court noted that the doctrine originated in water rights litigation but saw interstate fish runs as an analogous resource that could be allocated under the same principles. "A dispute over the water flowing through the Columbia-Snake River system would be resolved by the equitable apportionment doctrine; we see no reason to accord different treatment to a controversy over a similar resource of that system." 106 The Court concluded that, although Idaho could not claim ownership of the fish themselves, it did have an equitable right to its fair share of the runs. ${ }^{107}$

Idaho argued that it was not receiving its fair share because Oregon and Washington were allowing too much commercial and sport fishing of the runs, depleting the populations and preventing enough adults from reaching Idaho waters. ${ }^{108}$ A complex set of legal arrangements governed the allowable "harvest" of these runs and the allocation of that harvest between Oregon and Washington and also between Indian and non-Indian fishers. ${ }^{109}$ With the tribal share of the harvest protected by treaties and judicial decisions, ${ }^{110}$ Idaho sought only to establish a right

101. Idaho ex rel. Evans v. Oregon (Idaho II), 462 U.S. 1017, 1029 (1983).

102. Id. at 1018-19.

103. Id. at 1019-20.

104. Id. at 1020 .

105. Id. at 1023 (noting that the parties dispute the reasons for the declining runs of these species).

106. Id. at 1024. The Court also observed, "Much as in a water dispute, a State that overfishes a run downstream deprives an upstream State of the fish it would otherwise receive." Id.

107. Id. at 1025 .

108. Id. at 1028 n.12 (addressing Idaho's allegations of overfishing and mismanagement by the downstream states).

109. The Court discussed these arrangements in some detail in its opinion dealing with whether the case must be dismissed for failure to join the United States. Idaho I, 444 U.S. 380, 383-85 (1980).

110. The Court summarized years of litigation between tribes and the States of Oregon and Washington, ultimately resulting in a decision awarding the tribes a treaty-based right to half of the Columbia River salmon harvest. Id. at 384 (citing Sohappy v. Smith, 529 F.2d 570 (9th Cir. 1976)). 
to a portion of the non-Indian harvest of the Columbia-Snake runs. ${ }^{111}$ Unlike the downstream states, which had both commercial and recreational fishing, Idaho's fishery was entirely recreational. ${ }^{112}$

While Idaho alleged overfishing, ${ }^{113}$ the Court noted another reason for the declining fish runs: a string of federal dams on the Columbia and Snake Rivers, each of which took a toll on populations of juvenile and adult salmon attempting to migrate past them. ${ }^{114}$ The federal dams had such an impact that they were a major reason the special master recommended dismissal of Idaho's lawsuit for failure to join the United States. ${ }^{115}$ The Court did not see the special master's argument as a compelling reason to dismiss the case because even though the dams had major impacts on the salmon runs, ${ }^{116}$ Idaho was not seeking any changes in dam operations. ${ }^{117}$ Without the United States in the case, the parties had to accept federal dam operations as a given. ${ }^{118}$ Beginning in the 1990s, those operations would be the focus of a series of cases involving the government's compliance with the Endangered Species Act. ${ }^{119}$

In the end, Idaho failed to show that the actions of the downstream states had prevented the state from getting its fair share of the salmon. The special master and the Court in Idaho II reached this result largely by focusing narrowly on the period from 1975 through 1980, during which Idaho took more than half of the available harvest of these runs. ${ }^{120}$ Thus, the Court denied relief despite acknowledging that "Oregon and Washington may have harvested a disproportionate share of the [runs] over the long run," ${ }^{121}$ and may have allowed some overfishing of runs

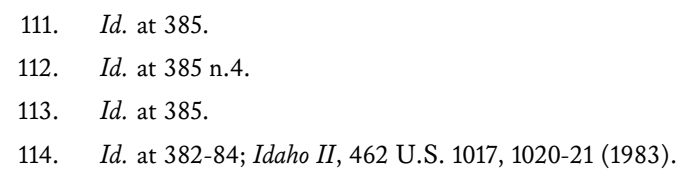

115. The other reasons were the federal government's control over salmon fishing in the Pacific Ocean, and the role of the United States as trustee for the tribes with treaty-based fishing rights. Idaho I, 444 U.S. at 387.

116. Id. at 388 :

We do not find this consideration a persuasive reason for dismissing Idaho's suit. We can assume, as suggested by defendants, that the eight dams along the Columbia and Snake Rivers are the primary reason why more fish do not successfully migrate back to Idaho. Nevertheless, Idaho stresses that it has no quarrel with the operation of the various dams.

117. Id.

118. In its later decision on the merits, the Court observed that "Idaho accepts, as it must, the continued operation of the dams and their adverse impact on the runs." Idaho II, 462 U.S. at 1027 n.11.

119. See Michael C. Blumm \& Aurora Paulsen, The Role of the Judge in ESA Implementation: District Judge James Redden and the Columbia Basin Salmon Saga, 32 STAN. ENVTL. L.J. 87, 110-142 (2013) (describing about 20 years of litigation over federal dam operations on the Columbia).

120. Idaho II, 462 U.S. at 1027-28.

121. Id. As the Court noted in a footnote, Idaho claimed that for the period 1962-1980, the downstream states had harvested the great majority of all the Idaho-origin fish from all three runs: $83 \%$ of spring chinook, $75 \%$ of summer chinook, and 58\% of steelhead originating in Idaho. Id. at 1028 n.12. 
as recently as $1974 .{ }^{122}$ Here, the Court split with three justices arguing in dissent that the special master and the Court had focused too narrowly on whether Idaho's share of the harvest had been fair from 1975 through $1980 .{ }^{123}$ Yet, all nine justices agreed that Idaho had a right to a fair share of the fish runs. ${ }^{124}$

\section{The Second North Platte Case: Endangered Species Habitat}

Resolving a three-state dispute over irrigation water supplies, the Court in 1945 divided the waters of the North Platte River primarily between Wyoming and Nebraska. ${ }^{125}$ The Court began its opinion by stating, "The controversy pertains to the use for irrigation purposes of the water of the North Platte River," ${ }^{126}$ and devoted 40 pages of factual, legal and equitable analysis to irrigation exclusively. ${ }^{127}$ The key outcome involved the "pivotal reach" of 41 river miles ending just below the Wyoming-Nebraska border, with the Court allocating 75 percent of irrigation season flows to Nebraska and 25 percent to Wyoming. ${ }^{128}$

Forty years later, Nebraska again sued Wyoming and Colorado over the waters of the North Platte. By the 1980s, the need for environmental flows to provide habitat for endangered birds along the Central Platte River in Nebraska had become a major concern for water users throughout the basin. ${ }^{129}$ In returning to the

122. Id. at $1028-29$.

123. Joined by Justices Brennan and Stevens, Justice O'Connor argued that the Court should have taken a longer view of the issue, and considered a broader range of factors in deciding whether Idaho was receiving her equitable share of the runs:

The Master should not have concluded that, simply because Idaho shared equally in the failure of the harvest in 1975-80, it had no further interest in promoting the conservation of the species and the eventual restoration of the runs, neither of which could occur without proper management practices on the part of the defendants.

Id. at 1034 (O'Connor, J., dissenting).

124. The two opinions saw this issue quite similarly for the most part. See id. at 1024-25; id. 1030-31 (O'Connor, J., dissenting). The dissent declared, "Idaho has a right to seek to maintain and eventually increase the runs by requiring the defendants to refrain from practices that prevent fish from returning to their spawning grounds in numbers sufficient to perpetuate the species in this river system." Id. at 1033 (O'Connor, J., dissenting).

125. Nebraska v. Wyoming, 325 U.S. 589, 637-54, 667-69 (1945) (Colorado, source of the North Platte headwaters, was also a party.).

126. Id. at 591.

127. See id. at 616-55. A single paragraph at the end of the opinion mentioned other uses, noting that the parties had agreed that the decree should not limit the use of water for "ordinary and usual domestic and municipal purposes." The Court agreed and added livestock watering to the list at Wyoming's suggestion. Id. at 656 .

128. See id. at 637-54, 667-69.

129. See John Echeverria, No Success Like Failure: The Platte River Collaborative Watershed Planning Process, 25 WM. \& MARY ENVT'L L \& POL'Y REV. 559, 565-70 (2001) (describing history of Platte River Basin endangered species controversies in the 1980s through the mid-1990s); see also Riverside Irrigation Dist. v. Andrews, 758 F.2d 508, 514 (10th Cir. 1985) (holding that Corps of Engineers must con- 
Supreme Court, Nebraska initially "sought modification of the decree to make Wyoming and Colorado share the burden of providing instream flows necessary to preserve critical wildlife habitat," ${ }^{130}$ but this motion was denied without explanation. ${ }^{131}$ Thus, the Court rejected Nebraska's attempt to expand the single-use 1945 decree into a multi-purpose allocation of the waters of the South Platte.

Environmental flows remained relevant in the litigation, however, as the Court later ruled that it would consider evidence of environmental injury in $\mathrm{Ne}$ braska in deciding whether to enjoin proposed upstream water projects. Wyoming argued that the earlier ruling foreclosed Nebraska from raising environmental issues, but the Court rejected that argument: " $[\mathrm{t}]_{\mathrm{o}}$ assign an affirmative obligation to protect wildlife is one thing; to consider all downstream effects of upstream development when assessing threats to equitable apportionment is quite another." ${ }^{132}$ Although the Court emphasized that Nebraska would have to show substantial injury in order to obtain relief, it gave Nebraska the opportunity to show that injury was based on harm to wildlife and wildlife habitat. ${ }^{133}$

That was the Court's last word on the subject, as the states eventually reached a settlement that modified the 1945 decree and included a set of detailed restrictions on water development and use in Wyoming. ${ }^{134}$ The states of Colorado, Nebraska, and Wyoming, as well as the federal government, would also agree on measures to improve environmental flows in Nebraska as part of a broader program to restore endangered species habitat along the Platte. ${ }^{135}$ Thus, even though the original decree did not provide for environmental flows and the Court refused to order them in the second case, the parties eventually came together in an effort to help the river and the species that depend on it. ${ }^{136}$ Meanwhile, the Court made it clear that the water needs of wildlife species and their habitat are relevant factors in an equitable apportionment proceeding.

sider impacts on Platte River endangered species habitat before issuing permit for new water project far upstream in Colorado).

130. Nebraska v. Wyoming, 515 U.S. 1, 12 (1995) (describing Nebraska's motion filed in 1988).

131. Id. (citing Nebraska v. Wyoming, 485 U.S. 931 (1988)).

132. Id.

133. The Court said that enjoining a proposed upstream project would mean modifying the 1945 decree. Before granting such relief, the Court would require Nebraska to show substantial injury, a burden it called "far from insignificant." Id. (citing Nebraska v. Wyoming, 507 U.S. 584, 592 (1993) (describing standards for enforcing vs. modifying an equitable apportionment decree)).

134. Nebraska v. Wyoming, 534 U.S. 40, 41 (2001) (noting final settlement); id. at 42-60 (specifying terms and conditions).

135. See U.S. DeP'T OF the Interior, Record of Decision, Platte River Recovery IMPLEMENTATION PROGRAM (2006).

136. See Reed Benson, Avoiding Jeopardy, Without the Questions: Recovery Implementation Programs for Endangered Species in Western River Basins, 2 MiCH. J. ENVTL. \& ADMIN. L. 473, 505-19 (2013) (summarizing basic features of the Platte River Recovery Implementation Program and other RIPs in western river basins). 
Consequently, in cases through the $20^{\text {th }}$ century, the Court established that it will consider harm to water quality and wildlife in deciding whether a state is receiving its equitable share of benefits from an interstate river. On the Delaware River, the Court issued a decree designed to protect water quality, fisheries, and recreation from harm caused by the actions of an upstream state. Today, Florida seeks a similar decree in its Supreme Court litigation against Georgia.

\section{FLORIDA V. GEORGIA: ENVIRONMENTAL FLOWS AND FEDERAL DAMS IN THE ACF BASIN}

\section{A. Prior Disputes and Corps Projects}

The ACF Basin covers much of western Georgia, a sliver of southeastern Alabama, and part of the Florida panhandle. The Chattahoochee and Flint Rivers both arise in northern Georgia; the longer Chattahoochee flows just west of Atlanta, forms the southern portion of the Alabama-Georgia border, and reaches Lake Seminole near the Florida border. At Lake Seminole, the Flint joins the Chattahoochee to form the Apalachicola River, which flows over 100 miles through Florida before reaching its estuary at Appachicola Bay. ${ }^{137}$ While the ACF may not be well known outside of water law circles, the Apalachicola is one of the major U.S. rivers in the Lower 48 states, with an average annual flow exceeding that of the Sacramento or the Hudson. ${ }^{138}$

The three states of the ACF Basin have been fighting over its water for a long time and much has been written about their dispute. ${ }^{139}$ While Georgia, Alabama, and Florida have been involved in litigation for much of the past 30 years, ${ }^{140}$ they also made efforts to reach an agreement over water allocation. There was even a temporary Apalachicola-Chattahoochee-Flint River Basin Compact, which com-

137. See Florida v. Georgia, 138 S. Ct. 2502, 2508-09 (2018) (describing the rivers as forming a "Y" with the Chattahoochee being its left arm, the Flint its right arm, and the Apalachicola its stem). A map of the basin appears as an appendix to the opinion at 2528.

138. LUNA B. LEOPOLD, A VIEW OF THE RIVER 99-101 (1994) (table showing statistics on the world's major river basins, including average annual discharge). Among U.S. river systems in the Lower 48, only the Mississippi, Columbia, Mobile, and Susquehanna are larger than the ACF by this measure. Id. The Apalachicola's average annual flow is roughly equal to that of the combined Sacramento and San Joaquin, though the ACF Basin is only half as large. Id. at 101, 104.

139. See, e.g., Carl Erhardt, The Battle Over "The Hooch": The Federal-Interstate Water Compact and the Resolution of Rights in the Chattahoochee River, 11 STAN. ENVTL. L.J. 200, 227 (1992); Dustin S. Stephenson, The Tri-State Compact: Falling Waters and Fading Opportunities, 16 J. LAND USE \& ENVTL. L. 83 (2000); Douglas L. Grant, Interstate Allocation of Rivers Before the United States Supreme Court: The Apalachicola-Chattahoochee-Flint River System, 21 GA. ST. U. L. REV. 401 (2004); George William Sherk, The Management of Interstate Water Conflicts in the Twenty-First Century: Is It Time to Call Uncle?, 12 N.Y.U. ENVTL. L.J. 764, 770-78 (2005).

140. In re MDL-1824 Tri-State Water Rights Litigation, 644 F.3d 1160, 1174-78 (11th Cir. 2011) (explaining litigation history). 
mitted the states "to develop an allocation formula for equitably apportioning the surface waters of the ACF Basin among the states while protecting the water quality, ecology, and biodiversity of the ACF." ${ }^{141}$ But this was little more than an agreement to agree, and when the states failed to settle on an allocation formula, the Compact lapsed in 2003. ${ }^{142}$

Much of the ACF water litigation has centered on the Corps' practices in operating a string of dams in the basin, primarily along the Chattahoochee. The lowest dam in the system, Jim Woodruff, creates Lake Seminole at the confluence that forms the Apalachicola. Congress authorized these dams for a variety of purposes including navigation, hydropower, and recreation. The Corps operates these dams as a system to achieve these purposes. ${ }^{143}$ Congress generally requires the Corps to "prescribe regulations for the use of storage allocated for flood control or navigation at all reservoirs constructed wholly or in part with Federal funds provided on the basis of such purposes, and the operation of any such project shall be in accordance with such purposes." ${ }^{144}$ The Corps thus develops "water control manuals" to guide the operation of its projects and "master manuals" for coordinated control of multiple projects on a particular river system. ${ }^{145}$ The Corps produced its first ACF manual in 1958, and it would remain in place for decades, in part because years of litigation delayed an update of the master manual. ${ }^{146}$ The Corps finally produced a new master manual for its ACF projects in $2017,{ }^{147}$ after completing an extensive environmental review process. ${ }^{148}$

Until recently, the main legal dispute over Corps projects in the ACF has focused on Lake Lanier, formed by Buford Dam on the Chattahoochee River, north of Atlanta. Georgia wanted significantly more of Lake Lanier's water to serve the growing needs of metropolitan Atlanta, but Alabama, Florida, and others interested in ACF water argued that they would be harmed if the Corps supplied that

141. Apalachicola-Chattahoochee-Flint River Basin Compact, Pub. L. No. 105-104, 111 Stat. 2219, 2222-23 (1997).

142. See Florida v. Georgia, 138 S. Ct. at 2509-10.

143. See id. at 2529-30 (Thomas, J., dissenting).

144. 33 U.S.C. $\S 709$ (2012). This language comes from Section 7 of the Flood Control Act of 1944, 58 Stat. 887, 890.

145. See infra Section I.B.

146. Florida v. Georgia, 138 S. Ct. at 2531 (Thomas, J., dissenting) (describing history of Corps' ACF manuals and related litigation).

147. U.S. ARMY CORPS OF ENG'RS, RECORD OF DECISION, APALACHICOLAChattahoochee-Flint Master Water Control Manual Update and Water Supply STORAGE ASSESSMENT 19 (2017) (decision formally adopting the updated master manual) [hereinafter ACF MANUAL ROD].

148. See U.S. ARMy CORPS OF Eng'Rs, Final EnVIRONMENTAL IMPACT STATEMENT, UPDATE OF THE WATER CONTROL MANUAL FOR THE APALACHICOLA-CHATTAHOOCHEE-FLINT

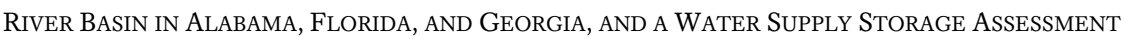
(2016) [hereinafter ACF MANUAL EIS]. This was a weighty Environmental Impact Statement, with Volume 1 alone roughly one thousand pages long, including a 47-page "executive summary." 
much water to Atlanta. ${ }^{149}$ A fundamental legal issue was the extent of the Corps' authority to commit Lake Lanier water for municipal purposes; both the Corps and a series of federal cases had found such authority lacking. ${ }^{150}$ But the $11^{\text {th }}$ Circuit Court of Appeals dug into the Corps' planning reports for Buford Dam and concluded that Atlanta's water supply was an authorized purpose of the project all along, ${ }^{151}$ therefore giving Georgia access to the water it wanted without the need for Congress to approve it. ${ }^{152}$ Based on that result, when the Corps issued its new ACF manual in 2017, it specifically allowed for reallocation of over a quarter million acre-feet of Lake Lanier water for use in Georgia. ${ }^{153}$ Despite losing the battle over Lake Lanier, Florida kept up its fight for the waters of the ACF Basin on a new front: interstate water litigation in the Supreme Court.

\section{B. Florida's Equitable Apportionment Action}

Florida filed its complaint for equitable apportionment and injunctive relief in the Supreme Court in 2013. ${ }^{154}$ Florida alleged that Georgia's growing consumption of water from the Chattahoochee and Flint Rivers for municipal, industrial, and agricultural purposes had significantly reduced flows in the Apalachicola. The result of these reduced flows, Florida contended, was environmental harm in the Apalachicola Basin and its enormously productive estuary, including collapse of the important oyster fishery in Apalachicola Bay. The complaint alleged that low flows in the Apalachicola were causing ecological, economic, and social harm to a part of Florida that was highly dependent on natural resources. Florida asked the Court to issue an equitable apportionment decree for the waters of the ACF Basin and an

149. Se. Fed. Power Customers v. Geren, 514 F.3d 1316, 1318-20 (D.C. Cir. 2008) (examining the long history of litigation over distribution of Lake Lanier water); Advocating for the Long-Term Health of Two Major River Basins, S. ENVTL. L. CTR, https://www.southernenvironment.org/cases-andprojects/tri-state-water-wars-al-ga-fl (last visited Nov. 12, 2018) (explaining the increasing water demands of Atlanta as a key driver of the Lake Lanier dispute).

150. Se. Fed. Power Customers, 514 F.3d at 1319 (noting Corps' conclusion in 2002 that it could not accommodate Georgia request without further Congressional authorization); id. at 1325 (finding that commitment of large volume of Lake Lanier water for municipal use in Georgia would be a major operational change requiring Congressional approval).

151. In re MDL-1824 Tri-State Water Rights Litigation, 644 F.3d 1160, 1186-92 (11th Cir. 2011).

152. The Corps had denied Georgia's request for additional water for Atlanta from Lake Lanier, but the $11^{\text {th }}$ Circuit - having held that the Corps did indeed have authority to grant that request - remanded the matter to the Corps to reconsider Georgia's request in light of that holding. Id. at 1192-97.

153. ACF MANUAL ROD, supra note 147, at 3. Final reallocation would require an agreement whereby Georgia would pay the Corps for the storage space.

154. Because the Supreme Court must grant permission to file a case within its original jurisdiction, Florida also filed a Motion for Leave to File a Complaint and a brief in support of that motion. The Supreme Court granted that motion in November 2014, allowing Florida's case to proceed. See Report of the Special Master at 14-16, Florida v. Georgia, 138 S. Ct. 2502 (2018) (No. 142, Orig.) [hereinafter Special Master's Report]. 
injunction capping Georgia's depletions. ${ }^{155}$ Georgia argued that Florida was suffering no significant harm, and to the extent there was significant harm, it was caused by the operations of Corps projects in the ACF Basin, not by Georgia's water uses. $^{156}$

By suing Georgia in the Supreme Court, Florida was effectively forced to shift its focus from Corps operations to non-federal water allocation, management, and use within Georgia. The United States has sovereign immunity in these interstate water cases, and some cases have not been allowed to proceed when the federal government refuses to be joined in the litigation. ${ }^{157}$ In cases (including the Columbia River salmon litigation ${ }^{158}$ ) where the United States is not a party but there is an important federal role relating to the merits of the litigation, the plaintiff state must establish that it can get effective relief without an order binding the federal government. ${ }^{159}$ For Florida, this means that it must be able to show harm caused by Georgia, not the Corps, and also establish that the Court can grant effective relief without a decree binding the Corps. ${ }^{160}$ Georgia sought to dismiss the case at the outset, arguing that the United States was an indispensable party, but the special master ${ }^{161}$ ruled that effective relief might be possible without federal involvement. ${ }^{162}$

Unable to attack the Corps' operations (or its decision to allocate a large amount of Lake Lanier storage for municipal and industrial use), Florida focused largely on Georgia's agricultural use. The Flint River supplies much of the irriga-

155. Id. at 16 (noting Florida's request to limit Georgia's depletions from the ACF Basin to 1992 levels).

156. Id. According to the special master, Georgia's position was "that Florida's asserted harms are imaginary, self-inflicted, or inflicted by the operations of [the Corps] or changes in precipitation patterns (or some combination thereof) but in any event cannot be traced to Georgia's water use." Id. at 2 .

157. See Arizona v. California, 298 U.S. 558, 559 (1936) (Lower Colorado River); Texas v. New Mexico, 352 U.S. 991 (1957) (Rio Grande). In some cases, the United States has opted to join the litigation to assert federal interests. See Nebraska v. Wyoming, 325 U.S. 589 (1945); Arizona v. California, 373 U.S. 546 (1963) (Lower Colorado River).

158. See infra Section II.B.

159. Idaho I, 444 U.S. 380, 387-92 (1980) (various runs of anadromous fish migrating between spawning grounds in Idaho and the Pacific Ocean). As the Court explained:

Idaho's narrow complaint is a two-edged sword. It has sidestepped the need to join the United States as a party by seeking only a share of the fish now being caught by nontreaty fishermen in Oregon and Washington. It now must shoulder the burden of proving that the nontreaty fisheries in those two states have adversely and unfairly affected the number of fish arriving in Idaho.

Id. at 392 .

160. Florida v. Georgia, 138 S. Ct. 2502, 2531-32 (2018) (Thomas, J., dissenting).

161. The Court in November 2014 appointed Ralph I. Lancaster as special master. See Special Master's Report, supra note 154, at 16-17. Special Master Lancaster is with the Pierce Atwood law firm in Portland, Maine. Id. (cover page).

162. See id. at 17-20. 
tion water for farmlands in southern Georgia, and unlike the Chattahoochee, there are no Corps dams on the Flint. ${ }^{163}$ Florida pointed to the enormous growth of agricultural water use in Georgia, offering evidence that irrigated acreage in that state had grown from 75,000 acres in 1970 to over 825,000 acres in $2014 .{ }^{164}$ The net effect of Georgia's increased consumption, Florida argued, was a substantial reduction in Apalachicola River flows, especially during the spring and summer of dry years. ${ }^{165}$

In his report, the special master was critical of Georgia's approach to the allocation and management of irrigation water, stating that "[e]ven the exceedingly modest measures Georgia has taken have proven remarkably ineffective." ${ }^{166}$ More specifically, he noted that Georgia had largely failed in the severe 2011-2012 drought to implement a state statute designed to reduce Flint River water use during droughts; ${ }^{167}$ continued approving new irrigation water use permits despite the concerns over drought impacts; ${ }^{168}$ and issued such permits without limiting the amount of water to be used in irrigation. ${ }^{169}$ While he stopped short of finding Georgia's agricultural water use unreasonable, he concluded, "Georgia's position practically, politically, and legally - can be summarized as follows: Georgia's agricultural water use should be subject to no limitations, regardless of the long-term consequences for the $[\mathrm{ACF}]$ Basin." 170

The special master also had "little question that Florida has suffered harm from decreased flows in the River." ${ }^{, 171}$ He noted that the Apalachicola Bay oyster fishery had experienced "unprecedent collapse" in the drought year of 2012, when

163. Florida v. Georgia, $138 \mathrm{~S}$. Ct. at 2508. The Court stated that "there are no dams along the Flint River," but it is more accurate to say that the Flint has no Corps dams; it has at least a couple non-federal ones. Special Master's Report, supra note 154, at app. C.

164. Special Master's Report, supra note 154, at 32-33. "Georgia's own estimates show a dramatic growth in consumptive water use for agricultural purposes." Id. at 33.

165. Id. at 15. This reduction was allegedly caused by all of Georgia's water development and use in the ACF Basin, not just by irrigation.

166. Id. at 33 .

167. Id.

For instance, although Georgia adopted the Flint River Drought Protection Act . . . in order to permit the State temporarily to 'buy back' agricultural irrigation rights at auction and thereby reduce water use during droughts, Georgia failed to implement the FRDPA's auction in 2011 and 2012 during one of the worst droughts on record.

Id. (citations omitted).

168. Id. at 34 (noting that Georgia had continued to approve backlogged permit applications, imposing only a temporary moratorium on new applications).

169. Id. at 33 .

170. Id. at 34. By contrast, he noted that Georgia appeared to have taken significant steps to have conserved water for municipal and industrial purposes in the Atlanta area, "though only after having been spurred to take such steps by adverse litigation results." Id. at 34 n.28.

171. Id. at 31 . 
"oyster mortality reached devastating levels" that virtually wiped out oysters in many areas that had been productive. ${ }^{172}$ The special master was apparently convinced that the mortality was caused by low flows in the river, resulting in higher salinity levels in the bay. ${ }^{173}$ The collapse of the fishery caused economic as well as ecological damage, leaving the future of Apalachicola Bay oyster harvesters in doubt. ${ }^{174} \mathrm{He}$ did not discuss whether Florida had shown environmental harm in any other way, though his report noted that the Apalachicola River supports "a unique ecosystem" that supports a remarkably diverse array of species. ${ }^{175}$

While the special master was seemingly convinced of Florida's harm and Georgia's "likely misuse of resources," on these points. Even assuming that unreasonable water use in Georgia was causing serious harm to Florida, the special master doubted that the Court could effectively remedy that harm without being able to bind the Corps. ${ }^{177}$ He then devoted about 35 pages - half the entire report, and nearly all of its analysis ${ }^{178}$ - to an examination of whether increased flows in the Flint River (due to limiting Georgia irrigation) would reliably translate to increased flows in the Apalachicola below the Jim Woodruff Dam. Despite the absence of Corps dams on the Flint, the special master concluded that improved flows on that river might not benefit the Apalachicola during dry seasons, based on the Corps' ability to withhold more water from its dams on the Chattahoochee and the operating protocols provided in the Corps' existing water control manual for its projects in the ACF Basin. ${ }^{179} \mathrm{He}$ found that the Corps:

172. $I d$.

173. He noted that the National Oceanic and Atmospheric Administration had reached this conclusion when it declared a fishery disaster for Apalachicola Bay in 2013. He noted that Georgia argued that the collapse was due to Florida's failure to manage the fishery appropriately but concluded that "the evidence presented tends to show that increased salinity rather than harvesting pressure led to the collapse." Id. at 31-32 (citations omitted).

174. Id. at 32 .

175. Id. at 8 (identifying endangered or threatened species of freshwater mussels that live in the Apalachicola River, along with the threatened Gulf sturgeon).

176. "As the evidentiary hearing made clear, Florida points to real harm and, at the very least, likely misuse of resources by Georgia." Id. at 31 .

177. In a key paragraph of his report, the special master wrote:

Much more could be said and would need to be said about these issues (as well as other issues, such as causation) were Florida and Georgia the only parties whose activities were implicated in this action. However, they are not. As already described, the Corps also conducts significant operations in the Basin. Regardless of the harm suffered by Florida and the unreasonableness of Georgia's agricultural water use, it is necessary to determine whether the activities of the Corps render uncertain any relief to Florida stemming from a Court decree capping Georgia's consumptive water use.

Id. at 34 .

178. Id. at 35-69. The "Analysis" section began on page 30, and the report ended on page 70.

179. Id. at $46-62$. 
[C]an likely offset increased streamflow in the Flint River by storing additional water in its reservoirs along the Chattahoochee River during dry periods. The evidence also shows that the Corps retains extensive discretion in the operation of those federal reservoirs. As a result, the Corps can release (or not release) water largely as it sees fit . . . ${ }^{180}$

Having concluded that Florida had failed to show by clear and convincing evidence that the Court could order an effective remedy in the Corps absence, he recommended that the Court deny Florida's request for relief. ${ }^{181}$

\section{The Court's 2018 Decision}

Florida's case survived, albeit barely, as a 5-4 majority held that the special master "applied too strict a standard when he determined that the Court would not be able to fashion an appropriate equitable decree." ${ }^{182}$ The Court ruled that the special master erred in requiring Florida to show by clear and convincing evidence that the remedy would be effective without Corps action. That level of proof on the remedy should not be required "unless and until the Special Master makes the findings of fact necessary to determine the nature and scope of likely harm caused by the absence of water and the amount of additional water necessary to ameliorate that harm significantly . ..." Until that point the complaining state need only establish, under principles of "flexibility and "approximation," that it is likely the Court could fashion a workable decree. ${ }^{184}$ Applying that standard, the Court ruled that Florida had done enough at this stage, and remanded the case to the special master for further proceedings. ${ }^{185}$

The Court made clear that environmental harm is relevant in determining whether a state is receiving its equitable share of the waters of an interstate river. The majority emphasized that all factors are relevant in an equitable apportionment determination, ${ }^{186}$ and stated that a key question on remand was whether a cap on Georgia's water consumption might increase flows in the Apalachicola enough to "significantly redress the economic and ecological harm that Florida has suf-

180. Id. at 69.
181. Id. at $70:$

Florida has not proven by clear and convincing evidence that any additional streamflow in the Flint River resulting from a decree imposing a consumptive cap on Georgia's water use would be released from Jim Woodruff Dam into the River at a time that would provide a material benefit to Florida.

182. Florida v. Georgia, 138 S. Ct. 2502, 2516 (2018).

183. Id.

184. Id. at $2516,2517$.

185. Id. at $2526-27$.

186. Id. at 2515 (quoting from earlier equitable apportionment cases and adding emphasis to the word "all"). 
fered[.]"187 The Court noted the special master's statements on the collapse of the oyster fishery and its impacts in Florida, involving both economic and ecological harm. And in the Court's clearest-ever statement regarding damage to the natural world under equitable apportionment, it observed:

The harms of reduced streamflow may extend to other species in the Apalachicola region, including in the river and its floodplain, which, as the Master noted, "is home to the highest species density of amphibians and reptiles in all of North America, and supports hundreds of endangered or threatened animal and plant species," including three "endangered" or "threatened" mussel species, the "threatened Gulf sturgeon," and the largest stand of Tupelo trees - of Tupelo Honey fame - in the world. $^{188}$

Thus, the Court indicated that harm to plant and animal species - endangered or not - is a relevant factor and did not suggest that a species must have some commercial use or value to be considered. ${ }^{189}$

The key issue for all nine justices, as it was for the special master, was the potential impact of Corps dams and their operations on flows in the Apalachicola River. The majority devoted about a third of its opinion to this issue, focusing heavily on the Corps' operating protocols for both drought and non-drought operations under the current Master Manual for its projects in the ACF Basin. ${ }^{190}$ The majority deduced that, "even when the Corps conducts its operations in accordance with the Master Manual, Florida's proposed consumption cap would likely mean more water in the Apalachicola...."191 In the end, the Court believed that a workable decree would be possible despite the Corps' "inherent discretion" in operating its projects. ${ }^{192}$

187. The Court actually broke this into two questions: to what extent would a cap on Georgia's consumption likely increase flows in the Apalachicola - a question that implicates Corps dams and their operations - and to what extent would those increased flows address Florida's harm. Id. at 2518.

188. Id. at 2519 (alterations omitted). The mention of "Tupelo Honey fame" refers to Van Morrison's soulful love song on the album of the same title. VAN MORRISON, TUPELO HONEY (Warner Bros. 1971).

189. This latter point presumably applies to most of the reptile and amphibian species found in the ACF Basin, which unlike oysters are not commercially harvested.

190. See Florida v. Georgia, 138 S. Ct. at 2519-26. The majority opinion runs from pp. 2508 to 2527.

191. The Court continued that existing operations should mean that the Apalachicola would receive "as much as $2,000 \mathrm{cfs}$ [cubic feet per second] more water when the Corps is conducting normal or 'non-drought operations,' and which could take place in dry periods, . . and $500 \mathrm{cfs}$ more on days when the Corps is conducting 'drought operations."' Id. at 2523.

192. Id. at 2526 (quoting the Special Master's Report at 56, n.38) (alterations omitted). 
The dissent, authored by Justice Thomas, ${ }^{193}$ seemingly took no issue with the majority on the relevance of environmental factors, ${ }^{194}$ but otherwise saw the case very differently. The dissent agreed with the special master on the legal standard he applied to Florida's request for relief. ${ }^{195}$ The dissent further contended that even if the standard were incorrect, "his findings are plainly correct and establish that Georgia should prevail under the balance-of-harms test." ${ }^{196}$ Finally, the dissent devoted roughly a quarter of its opinion ${ }^{197}$ to examining the effect of the Corps' operations. It took a very different view of the Master Manual's impact during drought periods, believing that they would effectively prevent increased flows in the Apalachicola even if more water came down the Flint. ${ }^{198}$ For the dissent, then, "the Special Master was correct to find that the Corps would not change its operations during droughts if this Court capped Georgia's water use and thus Florida would not benefit from a cap during droughts." 199

Both the majority and the dissent found support for their positions in the United States' amicus brief explaining the Corps' ACF operations, ${ }^{200}$ which carefully straddled the fence between the Florida and Georgia positions. On one hand, the United States explained that a cap on Georgia's consumption would mean higher flows in the Flint, resulting in more water reaching Florida under current Corps operating protocols. ${ }^{201}$ On the other hand, the brief stated that during drought operations in the ACF system, higher flows in the Flint would not likely result in higher flows in the Apalachicola because the Corps would likely release no more than 5,000 cubic feet per second (cfs) from the Jim Woodruff Dam and store

193. With Justice Thomas on the dissent were Justices Alito, Kagan, and Gorsuch. Id. at 2528 (Thomas, J., dissenting).

194. See id. at 2547 (discussing potential harm to species beyond oysters but noting that the special master had found only harm to oysters resulting from low flows in the Apalachicola). The dissent insisted, however, that the balance of harms would always favor Georgia because of Florida's small economic losses compared to the potential economic harm to Georgia of restricting agricultural uses. Id. at 2547-48. The dissent also emphasized that Georgia's portion of the ACF Basin - which, of course, includes the Atlanta metropolitan area - has a population of 5 million compared to 100,000 for the Florida portion of the Basin, and that the gross regional product is $\$ 283$ billion compared to $\$ 2$ billion. Id. at 2529.

195. Id. at 2536-37 (concluding that, contrary to the majority's view, the special master had appropriately "applied the ordinary balance-of-harms test dictated by this Court's precedents").

196. Id. at 2536, 2540-41.

197. See id. at 2541-46. The dissent runs from pp. 2528 to 2548.

198. See id. at 2542-45.

199. Id. at 2540. The dissent also insisted that Florida's only showing of harm was during drought periods. $I d$. at 2546-47.

200. Brief for the United States as Amicus Curiae, Florida v. Georgia, 138 S. Ct. 2502 (2018) (No. 142, Orig.) (Aug. 2017) [hereinafter U.S. Amicus Brief].

201. Id. at 16-17 (noting that higher flows in the Apalachicola were "more a question of timing than whether the flows would reach Florida at all"). 
the rest in upstream reservoirs. ${ }^{202}$ Thus, during drought operations, "Apalachicola River flows would be very similar with or without a consumption cap" on Georgia. ${ }^{203}$ But while higher flows in the Flint might not change the Corps' releases during drought operations, they could still benefit Florida by providing "an additional 'cushion,' delaying the onset of or hastening the recovery from drought operations," ${ }^{204}$ and thus allowing for fewer days where the release would not exceed $5,000 \mathrm{cfs}^{205}$ As for whether the Corps might change its operations to effect a Supreme Court decree, the United States reiterated the Corps' commitment to "take [that] into account and adjust its operations accordingly, including new or revised [Master Manuals] ..." ${ }^{206}$ But the brief seemed to walk back that statement, ${ }^{207}$ refusing to commit the Corps to making any operational changes based on a $\mathrm{Su}$ preme Court decree apportioning the waters of the ACF Basin. ${ }^{208}$

These somewhat contradictory statements allowed the majority and the dissent to take strikingly different views of whether the Corps' operating decisions would likely render ineffective any decree the Court might issue. The dissent flatly stated that "the Corps will not change its existing practices," regardless of what the Court might order. ${ }^{209}$ Except as provided in the existing Master Manual, the

202. Id. at 28. The brief noted that the 5,000 cfs minimum release during drought operations "was determined in consultation with the Fish and Wildlife Service to protect the threatened Gulf sturgeon" and the mussel species protected by the Endangered Species Act. Id. at 9.

203. Id. at 28. The dissent emphasized this point in concluding that Florida had not shown that capping Georgia's consumption would benefit the Apalachicola during drought periods, when it was clearly harmed by low flows. Florida v. Georgia, $138 \mathrm{~S}$. Ct. at 2545 (Thomas, J., dissenting).

204. U.S. Amicus Brief, supra note 200, at 18.

205. Florida v. Georgia, $138 \mathrm{~S}$. Ct. at 2522. The majority emphasized this point in concluding that Florida would obtain a measure of drought relief from a consumption cap on Georgia, even under the Corps' current operating protocols.

206. U.S. Amicus Brief, supra note 200, at 30 (quoting from the Corps' ACF MANUAL ROD, supra note 147 , at 18 ).

207. The brief stated that the Corps "stood by that statement" from its Record of Decision, but then said that the Corps "would have to consider" whether it could provide higher releases for Florida "under its existing authorities ....." Id. at 30.

208. The brief suggested the Corps would "consider" a Supreme Court decree in making ACF operating decisions:

Of course, a decision by the Court apportioning the waters of the ACF Basin, whether in the form of a consumption cap or something else, would necessarily form part of the constellation of laws to be considered by the Corps when deciding how best to operate the federal projects in the ACF Basin for their congressionally authorized purposes. But unlike a compact among the States that is approved by Congress or legislation altering the purposes of the ACF system, an apportionment by this Court in the form of a consumption cap would not formally bind the Corps to take any particular action because the United States is not a party to this suit, which has proceeded on the understanding that any relief must be shaped without mandating a change in the Corps' operations.

Id. at 32 .

209. Florida v. Georgia, 138 S. Ct. at 2541 (Thomas, J., dissenting). 
Corps would be unlikely to increase releases into the Apalachicola. ${ }^{210}$ As for whether the Corps might change the Master Manual, "there are a host of reasons to doubt the Corps would voluntarily change its procedures just because this Court capped Georgia's use." 211 In short, the dissent believed the Corps would simply ignore the Court.

The majority, by contrast, found reason to believe that the Corps would take steps to effectuate any decree the Court might issue. For one thing, the majority found it likely that increased flows in the Flint would pass through to Florida's benefit, even under the Corps' existing protocols. ${ }^{212}$ It also gave credence to federal statements that the Corps would "work to accommodate any determinations or obligations" set forth by the Court in an ACF Basin decree. ${ }^{213}$ Thus, while the majority recognized the "variety of circumstances and statutory obligations" 214 that drive the Corps' operating decisions, it believed that the Court could find a way to craft an effective decree - and that the Corps would help it do so. ${ }^{215}$

Though it allowed the case to proceed, the Court ended with a cautionary note, emphasizing that Florida would be entitled to relief only if it could show that the benefits of a decree would substantially outweigh the harm. ${ }^{216}$ That could prove exceedingly difficult, especially since all four dissenters believe that the balance of harms clearly tips in Georgia's favor, ${ }^{217}$ and since one member of the majority - Justice Kennedy - has retired. If and when the case returns to the Court, the Corps' operating protocols and practices could again become a crucial issue. In considering the role of federal dams in the ACF Basin, the Court must take a broader view of the legal and policy context in which the Corps makes operating decisions.

210. Id. at 2542 ("All available evidence suggests that the Corps would not exercise its discretion to release more water into the Apalachicola River during droughts.").

211. Id. For the dissent, these reasons include the Corps' operating history in the ACF Basin, the years of litigation over the prior manual revision, and the heavy procedural requirements associated with a new revision. Id. at 2544 .

212. Id. at 2520-21 (record shows it is "highly unlikely that the Corps will always reduce the flow" in the Apalachicola by storing all available water in excess of the 5,000 cfs minimum release during drought operations); id. at 2523 (projecting higher flows in drought and non-drought periods resulting from capping Georgia's consumption).

213. Id. at 2526

214. Id.

215. Although the special master believed that the Corps' inherent discretion in operating the ACF projects made effective relief highly uncertain, the majority determined that it could still produce a workable decree. "[T]he record leads us to believe that, if necessary and with the help of the United States, the Special Master, and the parties, we should be able to fashion one." Id.

216. Id. at 2528 (quoting from Colorado v. New Mexico I, 459 U.S. 176, 187 (1982)).

217. Id. at 2547 (Thomas, J., dissenting) (declaring that "it is clear who should prevail in this case"). 


\section{CAN FEDERAL DAMS Block EQUitable APPORTIONMENT?}

In its 2018 Florida v. Georgia decision, the Court had to decide whether Corps project operations would preclude effective relief of Florida's economic and environmental harm. In his report, the special master looked closely at the Corps' ACF operating regime and its potential effect on Apalachicola River flows. ${ }^{218}$ The Court's majority and dissenting opinions both did the same, ${ }^{219}$ even though they disagreed sharply on whether the regime could provide for a workable decree. The problem with both opinions, however, is that they focused too narrowly on the Corps' existing Master Manual for the ACF Basin, overlooking some important laws, policies, and principles regarding Corps operating decisions.

First, according to the Corps' own Water Control Management rules, ${ }^{220}$ water control plans ${ }^{221}$ are supposed to be reviewed at least every ten years ${ }^{222}$ and "revised as necessary to conform with changing requirements resulting from developments in the project area and downstream, improvements in technology, improved understanding of ecological response and sustainability, new legislation and other relevant factors, provided such revisions comply with existing federal regulations and established Corps policy." 223 In fact, in issuing its Biological Opinion under the $\mathrm{ESA}^{224}$ regarding the new ACF Master Manual, the Fish and Wildlife Service noted that the Master Manual was to be "reviewed every 5 years pursuant to [the Corps'] South Atlantic Division Policy," and therefore the Service issued its Biological Opinion "with the understanding that the [Manual] may be revised or up-

218. Special Master's Report, supra note 154, at 35-69.

219. Florida v. Georgia, 138 S. Ct. at 2520-25; id. at 2541-46 (Thomas, J., dissenting).

220. Water Control Management Rule, supra note 39.

221. Water control plans are to "include coordinated regulation schedules for project/system regulation and any additional provisions required to collect, analyze and disseminate data; prepare detailed operating instructions;" and operate projects safely and appropriately. Id., para. 3-2(b). Water control plans are then incorporated into water control manuals. $I d$.

222. Id., para. 3-2(j).

223. Id., para. 3-2(j)(1). This paragraph concludes, "[a]t any time during project implementation, it may be appropriate to revise the water control plan."

224. Section 7 of the Endangered Species Act prohibits any federal agency from taking an action that would jeopardize the continued existence of a threatened or endangered species. 16 U.S.C. $\S$ 1536(a)(2) (2012). To ensure that it meets this requirement, the agency before taking action must consult with the Fish \& Wildlife Service (or, for oceangoing species, the National Marine Fisheries Service) on the effects of the proposed action on listed species and their habitat. Id. The Service's Biological Opinion is its determination of the likely effects of the agency's action on those species. Id. $\S$ 1536(b). If an agency fails to consult on its proposed action - even an ongoing action, such as operation of a federal water project - it violates the Endangered Species Act. See, e.g., Pac. Coast Fed'n of Fishermen's Ass'ns v. Bureau of Reclamation, 138 F. Supp. 2d 1228, 1246-50 (2001) (finding violation by Bureau of Reclamation for failure to consult on its Klamath Project operations for 2000, and issuing injunction pending completion of consultation for 2001 operations, even though Bureau had completed consultation for years before 2000). 
dated within 5 years (i.e., in 2021) . . ."225 Thus, the 2017 ACF Master Manual is not a long-term fixture in determining flows in the Apalachicola River. To the contrary, per the Corps' own policies and rules the Master Manual should be reviewed no later than $2021,{ }^{226}$ or at the latest 2027 , and revised as needed to address factors far less weighty than a Supreme Court decree apportioning an interstate river. ${ }^{227}$

Second, while the Court recognized that the Corps must operate its projects in accordance with their congressionally authorized purposes, ${ }^{228}$ it may not have fully understood that the Corps retains much discretion in choosing how best to balance and serve those general purposes. In its amicus brief, the United States noted that Congress authorized the Corps' ACF Basin projects for multiples purposes, "including navigation, hydroelectric power, national defense, commercial value of riparian lands, recreation, and industrial and municipal water supply." 229 The United States did not suggest, however, that these authorized purposes could only be served by operating the projects in accordance with the 2017 Master Manual. In fact, in its Environmental Impact Statement for the ACF Master Manual revision, the Corps considered seven alternative operating regimes, each of which favored some purposes over others. ${ }^{230}$ Any of these alternatives seemingly would have served project purposes, as proposals that would have conflicted with them were not considered. ${ }^{231}$ Thus, while project purposes are set in statute, they leave the Corps a considerable range of options for meeting them - and while some options may appear better than others, those judgment calls are made by the Corps, not Congress. $^{232}$

225. U.S. Fish AND Wildlife SERV., Biological Opinion FOR ACF Water CONTROL MANUAL, EXECUTIVE SUMMARY 4 (2016) (noting that the Biological Opinion "will be reviewed, or consultation will be reinitiated at that time" when the Manual is reviewed).

226. This is doubly important because review of the Manual, whenever it happens, will involve a reinitiation of Endangered Species Act consultation. Id. A new Biological Opinion could make a meaningful difference for Apalachicola River flow levels during droughts, as the current 5,000 cfs minimum release from Jim Woodruff Dam was established largely to protect ESA-listed species. Special Master's Report, supra note 154, at 34; see also supra note 177. Thus, a new ESA consultation could result in a minimum flow level higher or lower than the established 5,000 cfs.

227. The GAO in 2015 found that the Corps does not actually update its water control plans regularly, despite the official policy, with funding constraints a primary reason for the delays. U.S. GOV'T ACCOUNTABILITY OFFICE, GAO-15-660, ARMY CORPS OF ENGINEERS: EFFORTS TO AsSESS THE IMPACT OF EXTREME WEATHER EVENTS 19 (2015). The report noted that some Corps officials had requested funding to update the plans, but the funding was not approved.

228. Florida v. Georgia, 138 S. Ct. 2502, 2526 (2018); see also id. at 2530 (Thomas, J., dissenting).

229. U.S. Amicus Brief, supra note 200, at 4 (citing various Corps project planning reports and statutes approving them).

230. ACF MANUAL EIS, supra note 148, at ES-18. The final EIS analyzed ten alternatives in detail, most of which were variations on the favored Alternative 7. Id. at ES-18 to ES-36.

231. Id. at ES-13.

232. ACF MANUAL ROD, supra note 147, at 1-10 (explaining alternatives studied, factors considered, and reasons for choosing the preferred alternative). 
Third, the Court should consider the incentives that would arise from allowing the Corps to effectively block equitable apportionment in the ACF Basin. In this case, the Corps' operating decisions may be found to preclude a workable decree; not because of any clear conflict with project purposes, ${ }^{233}$ but simply because the Corps will not be bound and will choose not to change its practices. If that happens, Georgia will have been allowed to exceed its fair share of the waters of an interstate river system ${ }^{234}$ due to the presence of federal dams in the basin. Given that there are well over a thousand federal dams on rivers across the nation, ${ }^{235}$ this could mean that equitable apportionment is practically unavailable on many interstate river systems. Of course, the Court continues to encourage states (and has encouraged the ACF Basin states) to resolve their water disputes by compact. ${ }^{236}$ But if an upstream state can defeat equitable apportionment simply by the presence of a federal dam, why would it choose to negotiate? ${ }^{237}$

This problem is presented not because the Corps is unable to join the case, but because it has chosen not to. Ironically, if this litigation were a general water rights adjudication in state court, the United States could be required to join the proceeding under the terms of a statute known as the McCarran Amendment. ${ }^{238}$ As interpreted by the Court, the McCarran Amendment has meant that even reserved right claims for federal and tribal lands under the Winters doctrine have been litigated in state courts, which puts those important federal interests in a forum generally seen as adverse or even hostile to them. ${ }^{239}$ Subjecting such federal and tribal

233. The dissent noted the tension between preserving project storage and increasing releases to the Apalachicola during drought periods. Florida v. Georgia, 138 S. Ct. at 2543 (Thomas, J., dissenting). But this kind of tension is inherent in the operation of projects with multiple purposes, especially when upstream and downstream states are involved, as illustrated by the multi-state litigation over the Corps' operation of its projects on the Missouri River. See In re Operation of the Mo. River Sys. Litig., 421 F.3d 618, 624-28 (8th Cir. 2005).

234. Neither the special master nor the Court has yet determined that Georgia is exceeding its fair share of ACF waters, although the special master did suggest that there has been, "at the very least, likely misuse of resources by Georgia." Special Master's Report, supra note 154, at 31.

235. The Bureau of Reclamation built more than 600 dams, while the Corps claims nearly 700 . About Us, U.S. BUREAU OF RECLAMATION, http://www.usbr.gov/main/about (last visited June 20, 2015); Dam Safety Program, U.S. ARMY CORPS OF ENGINEERS, http://www.usace.army.mil/ Missions/CivilWorks/DamSafetyProgram.aspx (last visited Aug. 7, 2014).

236. Florida v. Georgia, 138 S. Ct. at 2509 (citing several interstate water cases).

237. In years past, the prospect of federal money for new water projects gave states an incentive to enter into compacts. See Douglas L. Grant \& Gregory S. WEber, CASES AND Materials ON WATER LAW 495 (8th ed. 2010) (quoting Charles J. Meyers, The Colorado River, 19 STAN. L. REV. 1, 48 (1966)). Now that the federal government is not building many new big projects, however, the states no longer have that source of motivation to resolve their water disagreements through negotiation.

238. 43 U.S.C. $§ 666$ (1994) (giving consent to join the United States as a defendant in any "adjudication of rights to the use of water of a river system or other source," or for the administration of such rights, when the United States is the owner of water rights or in the process of acquiring them).

239. See Michael C. Blumm et al., The Mirage of Indian Water Rights and Western Streamflow Restoration in the McCarran Amendment Era: A Promise Unfulfilled, 36 ENVTL. L. 1157 (2006) (summarizing 
claims to state court jurisdiction was not specifically required by the statute but was necessary, said the Court, to effectuate its purpose of allowing all water right claims to be litigated in a single proceeding. ${ }^{240}$ This policy argument would seem far stronger in the case of interstate water litigation where the Court is the only available forum to settle these major disputes between sovereigns. ${ }^{241}$ But since there is nothing like the McCarran Amendment for Supreme Court cases, ${ }^{242}$ there is no way to force the United States to join the ACF litigation, even though the federal government no longer seems to have a compelling reason to stay out. ${ }^{243}$

Whatever else might be said about American water federalism, most observers would likely agree that the federal government should normally support a state's water management priorities. And if a federal agency is going to frustrate a key state goal, it should be necessary to serve an important national interest. Congress has repeatedly stated its respect for state primacy in water allocation and management, ${ }^{244}$ and importantly for the ACF Basin, did so in the 1944 Flood Control $\mathrm{Act}^{245}$ - a key source of authority for Corps projects nationally. ${ }^{246}$ In Section 1 of

Supreme Court's application of McCarran Amendment, subjecting tribal claims to state court jurisdiction and criticizing state courts' handling of tribal reserved right claims in a series of cases).

240. Reed D. Benson, Deflating the Deference Myth: National Interests vs. State Authority Under Federal Laws Affecting Water Use, 2006 UTAH L. REV. 241, 268-69 (2006) (explaining series of Supreme Court cases interpreting the McCarran Amendment).

241. See Florida v. Georgia, 138 S. Ct. at 2512-16 (explaining basic principles of these interstate cases).

242. Congress may want to consider waiving federal sovereign immunity for interstate litigation in the Supreme Court, at least on a case-by-case basis. In the case of Florida v. Georgia, allowing joinder of the United States would provide a judicial forum that includes all the key sovereigns in the ACF Basin. Without such a forum it seems much less likely that the ACF Basin states could agree on a water allocation compact. See id. at 2511. Congress in 2014 specifically urged the ACF states to develop a compact, Water Resources Reform and Development Act of 2014, Pub. L. No. 113-121, § 1051, 128 Stat. 1193,1259 , though it repealed that language two years later. Water Infrastructure Improvements for the Nation Act, Pub. L. No. 114-322, § 1187, 130 Stat. 1628, 1681 (2016).

243. The federal government's amicus brief states that:

the United States did not intervene in this action in large part to avoid being bound by a decree that could directly affect Corps operations before the Corps had a chance to finally complete its process of updating the Master Manual and individual reservoir regulation manuals for the ACF Basin ....

U.S. Amicus Brief, supra note 200, at 32. The brief did not explain why, since the Corps adopted its new Master Manual in March 2017, the Corps still believes that it should not join the litigation.

244. See, e.g., United States v. New Mexico, 438 U.S. 696, 702 n.5 (1978) (referring to a list of "37 statutes in which Congress has expressly recognized the importance of deferring to state water law").

245. Flood Control Act of 1944, ch. 665, 58 Stat. 887 (codified in scattered sections of multiple titles of the U.S. Code).

246. For example, Section 7 of the 1944 Act required the Secretary of War "to prescribe regulations for the use of storage allocated for flood control or navigation at all reservoirs constructed wholly or in part with Federal funds provided on the basis of such purposes, and the operation of any such projects shall be in accordance with such regulations ... ." 33 U.S.C. $\S 709$ (2012). Recreational use of 
the 1944 Act, Congress declared a policy "to recognize the interests and rights of the States in determining the development of the watersheds within their borders and likewise their interests and rights in water utilization and control . .."247 Congress specifically directed the Corps to consult with affected states in the course of investigating potential projects, to send its reports on recommended projects to the affected states for review and comment, and to provide any state comments to Congress along with the underlying Corps reports. ${ }^{248}$

Congress thus ensured that affected States, consistent with their "interests and rights" in water management, have a voice in the investigation, planning, and authorization of Corps projects. ${ }^{249}$ Given this framework of cooperative federalism, ${ }^{250}$ it is remarkable that the Corps, simply to protect its operating plan, might ultimately prevent Florida from vindicating its equitable right to the waters of the ACF Basin. ${ }^{251}$ It is also remarkable that the Corps could take that position, effectively putting Florida's rights in great peril, yet receive no criticism from Supreme Court justices who often question the exercise of agency discretion. ${ }^{252}$

It remains true, of course, that without a waiver of the United States' sovereign immunity, the Court cannot issue a decree that will officially bind the Corps. But if Florida makes its case for relief, the Court must not deny a remedy simply because it cannot force the Corps to make any changes in its operations. That result would practically elevate an agency's project operating plan over a state's right to equitable apportionment, ignoring the true status of that operating plan and turning basic notions of American water law upside down.

Corps projects was addressed in Section 4, 16 U.S.C. $\S 460$ d, marketing of hydropower generated at Corps dams was authorized in Section 5, 16 U.S.C. $\S 825$ s, and so on.

247. 33 U.S.C. $\S 701-1$ (2012) (codifying Section 1 of the Flood Control Act of 1944).

248. See id. $\S 701-1(\mathrm{a})$.

249. See id. The Corps' investigations of potential projects:

shall be conducted in such a manner as to give to the affected State or States, during the course of the investigations, information developed by the investigations and also opportunity for consultation regarding plans and proposals, and to the extent deemed practicable by the Chief of Engineers, opportunity to cooperate in the investigations.

Id.

250. The Court emphasized cooperative federalism in the context of Bureau of Reclamation projects, holding that federal law requires the Bureau to comply with requirements of state water law so long as they are "not inconsistent" with Congressional directives. See e.g., California v. United States, 438 U.S. 645, 674 (1978). The Court stressed "cooperative federalism,", and in emphasizing Congressional deference to state water law, it quoted Section 1 of the Flood Control Act. Id. at 650-51, 678.

251. Apalachicola River flows have been protected under state law since 2006, when the Northwest Florida Water Management District acted to reserve the "magnitude, duration and frequency of observed flows . . . for the protection of fish and wildlife of the river, floodplain and Apalachicola Bay." FLA. AdMIN. CODE ANN. r. 40A-2.223 (2014).

252. I refer here to the staunchly conservative dissenters in Florida v. Georgia, Justices Alito, Gorsuch, and Thomas. See generally Florida v. Georgia 138 S. Ct. 2502, 2528-48 (2018) (Thomas, J., dissenting) (dissenters broadly approving of the Corps' position in the case). 


\section{CONCLUSION}

Florida v. Georgia lives on, as the Supreme Court narrowly rejected the special master's recommendation to deny relief. But Florida still has a high hill to climb before it earns an equitable apportionment decree. Although it has already shown that low flows have caused "real harm" in the collapse of the Apalachicola Bay oyster fishery, it must further establish that a decree would bring benefits to Florida that would "substantially outweigh the harm" to Georgia, ${ }^{253}$ which has always been a difficult burden for the complaining state in these cases. ${ }^{254}$ The Court has suggested that the special master may need to make more detailed findings on a range of factual issues regarding Florida's harm, Georgia's use, and the Corps' influence. ${ }^{255}$

The United States remains a non-party, which nearly ended the case when the special master concluded that effective relief could not be assured without the Corps. The Court narrowly disagreed, but the role of the Corps and its projects still looms large in the dispute. ${ }^{256}$ To the extent that Florida can show that it has been harmed by the flow regime on the Apalachicola, Georgia is sure to argue that the harm was caused by the existence and operations of the Corps' string of dams in ACF Basin, which Florida cannot contest in this proceeding. Assuming that Florida can show it is entitled to relief, the Court will have to determine finally whether it can order an effective remedy without being able to bind the Corps. In considering the effects of the Corps' project operations, whether in determining causation or deciding on a remedy, the Court must see the 2017 Master Manual for what it is: an agency operating plan that may bind the Corps, ${ }^{257}$ but is not a permanent and immutable part of the law of the ACF Basin.

The case may well turn on whether Florida can establish that low flows in the river are causing significant environmental harm, and whether the Court sees that kind of harm as important enough to warrant restrictions on Georgia's consumptive uses. It seems likely that Florida must prove harm that goes beyond oysters, valuable as they are, because four members of the Court have already declared that the losses of the oyster fishery can never outweigh the harm to Georgia's agricultural users. If the value of a river is nothing more than economic, the Court will likely deny relief. ${ }^{258}$ But the Court has already noted that the ACF Basin supports a rich and unique ecosystem that is home to a diverse array of species, all relying to

253. Id. at 2527 .

254. See infra Section I.A.

255. Florida v. Georgia, $138 \mathrm{~S}$. Ct. at 2527 (laying out questions to be addressed, which are essentially the same ones identified and examined in Part IV of the majority opinion, $i d$. at 2517-26).

256. See infra Section III.C.

257. See South Dakota v. Ubbelohde, 330 F.3d 1014, 1027-30 (8th Cir. 2003) (ruling that the Corps' Master Manual for operating its Missouri River Basin projects was binding on the Corps).

258. See supra notes 188-89 and accompanying text. 
some degree upon adequate flows. ${ }^{259}$ And if, as Justice Holmes wrote, a river is a treasure - whose value is not just in the dollars it generates but also the life it sustains - then environmental flows will carry real weight in equitable apportionment. The future of the Apalachicola may turn on the Court's view of the true worth of a river.

259. See supra notes $190-99$ and accompanying text. 